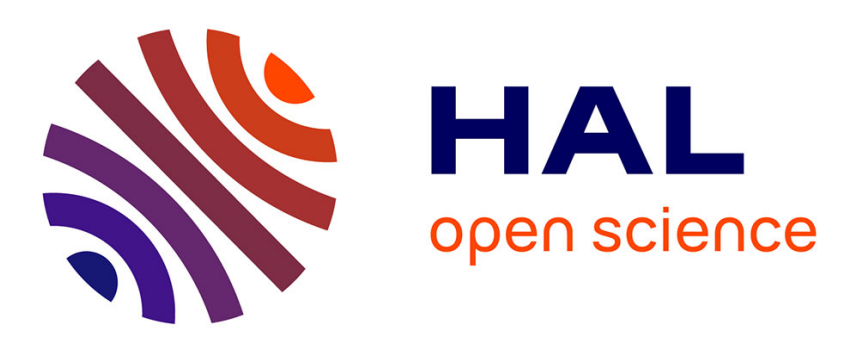

\title{
Recent Trends in Elaboration, Processing, and Derivatization of Cellulosic Materials Using Ionic Liquids
}

\author{
Ahmed Salama, Peter Hesemann
}

\section{- To cite this version:}

Ahmed Salama, Peter Hesemann. Recent Trends in Elaboration, Processing, and Derivatization of Cellulosic Materials Using Ionic Liquids. ACS Sustainable Chemistry \& Engineering, 2020, 8 (49), pp.17893-17907. 10.1021/acssuschemeng.0c06913 . hal-03117219

\section{HAL Id: hal-03117219 \\ https://hal.umontpellier.fr/hal-03117219}

Submitted on 13 May 2021

HAL is a multi-disciplinary open access archive for the deposit and dissemination of scientific research documents, whether they are published or not. The documents may come from teaching and research institutions in France or abroad, or from public or private research centers.
L'archive ouverte pluridisciplinaire HAL, est destinée au dépôt et à la diffusion de documents scientifiques de niveau recherche, publiés ou non, émanant des établissements d'enseignement et de recherche français ou étrangers, des laboratoires publics ou privés. 


\title{
Recent trends in elaboration, processing and derivatization of cellulosic materials using ionic liquids
}

\author{
Ahmed Salama ${ }^{1,2}$ and Peter Hesemann*1 \\ ${ }^{1}$ Institut Charles Gerhardt de Montpellier, UMR CNRS 5253 Université de \\ Montpellier-CNRS-ENSCM, Place Eugène Bataillon, 34095 Montpellier Cedex 05, \\ France
}

${ }^{2}$ Cellulose and Paper Department, National Research Centre, 33 El-Behouth St., Dokki, P.O. 12622, Giza, Egypt

*Corresponding author: email: peter.hesemann@ umontpellier.fr phone: +33-4.67.14.45.28 


\begin{abstract}
Sustainable biopolymers are promising raw resources for the development of novel biomaterials with vast potential in various application fields. Nonetheless, the processing and derivatization of biomaterials is still a challenge due to the low solubility, especially of cellulose, in common solvents. Since the discovery that most biopolymers display significant solubility in ionic liquids (ILs), this method opened new routes for processing and derivatization of such compounds, thus allowing the access to novel materials with new structures and properties. IL processing has been shown to allow $(i)$ accessing novel cellulose materials with controlled texture, crystallinity and morphology; (ii) derivatization of cellulose via chemical modification, and finally (iii) formation of cellulose based ionogels, blends and composites. This review discusses recent progress in IL related techniques that have recently been developed to synthesize new cellulose derivatives and to access cellulose-based functional materials such as polymer electrolytes, polymer composites, and electrospun fibers. These examples highlight the high potential of these novel cellulose derived materials for the design of cellulose based electrochemical devices, wound care materials, drug delivery systems, tissue engineering biomaterials, and other applications, thus representing a step forward towards sustainable and bio sourced functional materials.
\end{abstract}

\title{
Keywords
}

Ionic liquids - Cellulose - Composites - Cellulose derivatives - Extraction 


\section{Graphical Abstract}

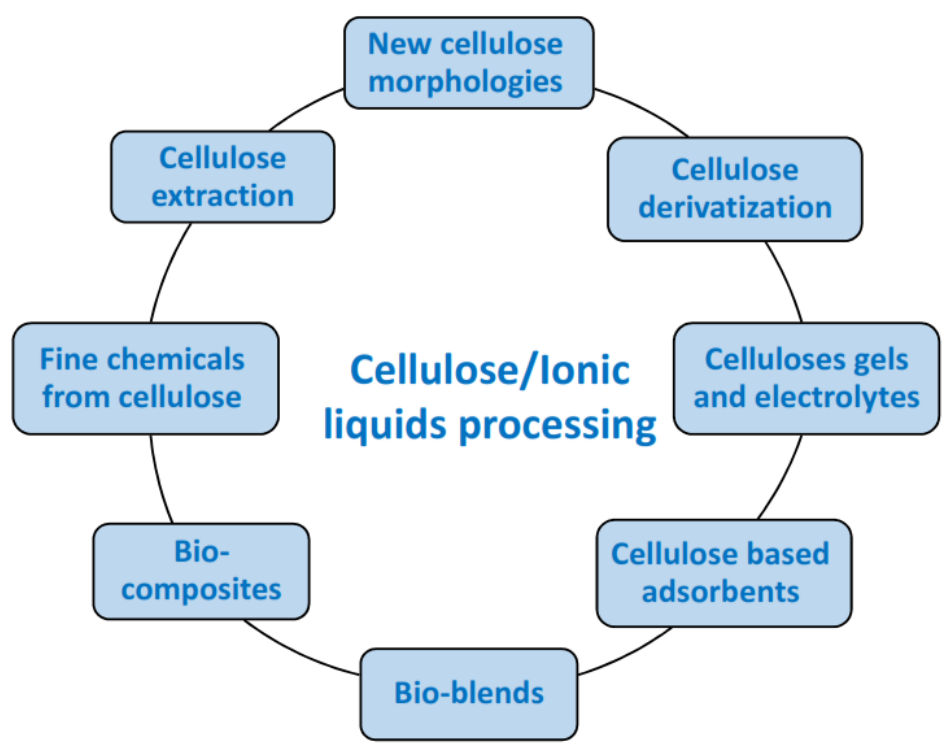

\section{Synopsis}

Environmentally benign ionic liquid based strategies for cellulose derivatization to access functional materials from renewable resources. 


\section{List of abbreviations}

\begin{tabular}{|c|c|}
\hline ILs & Ionic Liquids \\
\hline$\left[\mathrm{C}_{4} \mathrm{mim}\right] \mathrm{Cl}$ & 1-butyl-3-methylimidazolium chloride \\
\hline DMSO & Dimethyl sulfoxide \\
\hline $\mathrm{DS}$ & Degree of substitution \\
\hline $\mathrm{PhCF}$ & Phenyl chloroformate \\
\hline$\left[\mathrm{C}_{2} \mathrm{mim}\right] \mathrm{OAc}$ & 1-ethyl-3-methylimidazolium acetate \\
\hline PAN & poly(acrylonitrile) \\
\hline$[\mathrm{Amim}] \mathrm{Cl}$ & 1-allyl-3-methylimidazolium chloride \\
\hline HPC & Hydroxypropyl cellulose \\
\hline$\left[\mathrm{C}_{4} \mathrm{mim}\right] \mathrm{OAc}$ & 1-butyl-3-methylimidazolium acetate \\
\hline$\left[\mathrm{C}_{4} \mathrm{mim}\right] \mathrm{NTf}_{2}$ & $\begin{array}{l}\text { 1-butyl-3-methylimidazolium } \\
\text { bis(trifluoromethylsulfonyl)imide }\end{array}$ \\
\hline$\left[\mathrm{C}_{2} \mathrm{mim}\right] \mathrm{Pr}$ & 1-ethyl-3-methylimidazolium propionate \\
\hline GO & graphene oxide \\
\hline$\left[\mathrm{C}_{2} \mathrm{mim}\right] \mathrm{DEP}$ & 1-ethyl-3-methylimidazolium diethyl phosphate \\
\hline [P8881]OAc & trioctylphosphonium acetate \\
\hline$[\mathrm{Emim}] \mathrm{OAc}$ & 1-ethyl-3-methylimidazolium acetate \\
\hline$[\mathrm{P} 8885] \mathrm{HSO}_{4}$ & Trioctyl-pentylphosphonium hydrogen sulfate \\
\hline HMF & 5-hydroxymethylfurfural \\
\hline
\end{tabular}




\section{Introduction}

The shortage of petroleum, coal and other nonrenewable resources inspires scientists to develop more sustainable alternatives in particular from natural resources. In materials chemistry, the elaboration of biobased materials from renewable resources attracted huge interest and became a domain with intense research activities in the last few years ${ }^{1-4}$. Biosourced polymers are linear polymers based on different repeating units. They can be classified mainly into $i$ ) polysaccharides, consisting of sugar units, $i$ ) proteins based on amino acids, and finally $\mathrm{iii}$ ) nucleic acids, consisting of nucleotides ${ }^{5}$. These polymers have emerged as sustainable materials which can reduce the dependency on limited non-renewable resources and allow protection of the environment ${ }^{6,7}$. Cellulose is the most abundant biomass resource, mainly extracted from the natural plants ${ }^{8,9}$. Moreover, cellulose exhibits characteristics of renewability, biodegradability, biocompatibility and environmental friendliness. However, the use of cellulose in fine applications was largely hampered by its poor solubility in conventional solvents, thus limiting its derivatization and processing. Only few particular molecular solvents such as $\mathrm{N}$-methylmorpholine oxide (NMMO), $\mathrm{N}, \mathrm{N}$-dimethylacetamide/lithium chloride (DMAc/LiCl), 1,3-dimethyl-2-imidazolidinone/lithium chloride (DMI)/LiCl are able to dissolve biopolymers such as cellulose, chitin and wool. These conventional methods for dissolving biopolymers exhibit significant drawbacks involving non-trivial operation processes, severe pollution, high reagent and energy consumption, and finally inefficient solvent recycling due to solvent evaporation.

In 2002, Rogers et al. reported that ionic liquids such as 1-butyl-3-methylimidazolium chloride $\left(\left[\mathrm{C}_{4} \mathrm{mim}\right] \mathrm{Cl}\right)$ efficiently dissolve up to $25 \mathrm{wt} . \%$ of cellulose ${ }^{10}$. This finding opened routes toward novel processing strategies of biopolymers from homogeneous IL solution. In the following, many examples for the use of ILs in biopolymer processing have been reported. Besides cellulose, ILs appeared as highly suitable solvents for various biopolymers such as chitin ${ }^{11}$, wool ${ }^{12}$ and silk ${ }^{13}$. IL processing of these materials led to new materials with new application profiles. In particular, ionic liquids offer an efficient and green alternative for the chemical modification of cellulose. This minireview focuses on recent examples for IL based cellulose processing in view of the design and elaboration of novel functional cellulose derived materials. It treats in particular recent trends in the formation of novel cellulose modifications such as cellulose fibers, the derivatization of cellulose via chemical 
modification in IL media, and finally the formation of cellulose composites and blends. We will show that IL processing opens new perspectives to access functional biosourced materials for a large panel of applications.

\section{Processing of cellulose using ionic liquids}

Cellulose is the most abundant bio renewable polymer on the earth which constitutes $35-50 \%$ of the more than $170 \times 10^{9}$ tons of lignocellulosic biomass produced annually 14. It has been widely used in our daily life, such as in paper, clothing, coating, tissues, medicines and composites materials ${ }^{15,16}$. Cellulose is a linear homopolymer consisting of $\beta-1,4$ linked glucopyranose units ${ }^{17}$. The properties of cellulose can be adjusted by varying the distribution of functional groups within the anhydroglucose units ${ }^{18}$, and the functionalization of all hydroxyl groups of cellulose produces a uniform homopolymer with new properties. Neat cellulose does not dissolve in conventional organic or aqueous solvents and the traditional methods for dissolving cellulose show drawbacks such as severe pollution, large reagent consumption, high energy consumption and solvent evaporation. The strong intra- and intermolecular hydrogen bonds within cellulose, together with its crystallinity, are the main reasons for the low solubility of cellulose in common solvents ${ }^{19}$ and result in its limited processability. Only solvents that can break these bonds are capable to solubilize cellulose. However, most of these solvents [i.e., $N, N$ dimethylacetamide-lithium chloride and dimethyl sulfoxidetetrabutyl ammonium fluoride] are toxic, thermally unstable, volatile and difficult to recycle. These solvents or solvent mixtures are therefore not sustainable ${ }^{14}$, and new solutions for cellulose dissolution and processing are therefore highly desirable.

Ionic liquids are molten salts that are exclusively composed of organic cations and organic/inorganic anions. By definition, ILs display melting temperatures below 100 ${ }^{\circ} \mathrm{C}$. Their properties can be tailored by varying the chemical nature of cations and anions

20. The unique properties of ILs such as high ion conductivity, low vapor pressure, tunable miscibility with water and/or organic solvents and high thermal stability distinguish ILs from conventional molecular organic solvents. ILs are considered as supramolecular solvents, as they form large supramolecular networks via hydrogen bonding. In this way, several ILs form nanostructures with polar and non-polar domains 21.

Following the publication of Rogers et al. highlighting that ionic liquids such as 1butyl-3-methylimidazolium chloride $\left(\left[\mathrm{C}_{4} \mathrm{mim}\right] \mathrm{Cl}\right)$ efficiently dissolve up to $25 \mathrm{wt} . \%$ of 
cellulose ${ }^{10}$, a large variety of other ILs were studied for cellulose dissolution. It has been shown that ILs based on imidazolium, pyridinium, morpholinium and pyrrolidinium cations are suitable solvents for cellulose ${ }^{22}$. The presence of aprotic cosolvents such as DMSO can further increase the dissolution properties ${ }^{23}$. The most efficient anions are $\mathrm{Cl}^{-}, \mathrm{OAc}^{-}, \mathrm{HCOO}^{-},(\mathrm{EtO})_{2} \mathrm{PO}_{2}^{-}$while ILs containing noncoordinating anions such as $\mathrm{PF}_{6}^{-}$or $\mathrm{NTf}_{2}^{-}$are inefficient for cellulose dissolution.

Promising trials have been carried out to minimize the degradation of cellulose and to investigate non-derivatizing single-component ionic liquids for cellulose dissolution. For example, Samikannu et al. studied lutidinium-based ILs such as 1-allyl-3,5dimethylpyridinium chloride and 1-allyl-3,4-dimethylpyridinium chloride for cellulose dissolution. The dissolution-reprecipitation process resulted in cellulosic materials displaying reduced crystallinity while its thermal stability was close to that of native cellulose ${ }^{24}$.

The mechanism of cellulose dissolution in ionic liquids is based on the hydrogen bond formation between the ionic liquid and the hydroxyl groups of cellulose. Both cation and anion are involved in the dissolution mechanism ${ }^{25}$. The hydrogen bonding abilities of ILs therefore appear as a principal reason for their cellulose dissolution properties. Transmission electron microscopy studies showed that the dissolution of cellulose started by the depolymerization of the fibers followed by gradual dissolution. Finally, a stable mixture of cellulose chains in IL is formed ${ }^{26}$. Due to the strong interactions with cellulose, ILs such as $\left[\mathrm{C}_{4} \mathrm{mim}\right] \mathrm{Cl}$ can be 'attached' on biopolymers via hydrogen bonding because $\left[\mathrm{C}_{4} \mathrm{mim}\right] \mathrm{Cl}$ cations have hydrogen-bond donating ability and cellulose has hydrogen bond accepting properties. However, the role of the cations and the contribution of hydrophobic interaction during cellulose dissolution is still under investigation $^{27}$.

The development of efficient, green and low energy consuming techniques for cellulose dissolution and processing is crucial for future product developments. The availability of more sustainable cellulose processing strategies will open new perspectives for applications of cellulose based materials. After the groundbreaking report of Rogers et al., the performance of various ILs to dissolve cellulose has systematically been studied 28. The IL-technology therefore allows modifying the microstructure of cellulose and obtaining materials with new architectures and morphologies. It is a promising research field with great perspectives and high potential for industrial applications. Cellulose processing in ILs opens the access to new cellulose-based materials with outstanding 
properties, like super-microfibers, precursors for carbon fibers, and all-cellulose composites. The aim of this minireview is to summarize some recent trends in this area.

\section{New cellulose morphologies: Ionic liquid assisted cellulose spinning}

ILs based processing of cellulose opens the route to a new type of cellulose fibers with unique properties ${ }^{29}$. As an example, it opens the route towards the production of supermicrofiber filaments for textiles and filters applications ${ }^{30}$. The regenerated cellulose fibers are spun from cellulose/ILs solutions by a dry-jet wet spinning technique. It has been reported that the formation of optically anisotropic solutions by dissolving cellulose in ILs can enhance the spinnability of fibers ${ }^{31}$, and the regenerated fibers prepared from these solutions exhibit improved mechanical properties due to their intrinsic, highly oriented assembly of the cellulose chains, and strong intermolecular hydrogen bonds between them ${ }^{32}$. Zhu et al. transferred low molecular weight microcrystalline cellulose into stiff regenerated cellulose fibers using a dry-jet wet fiber spinning technique from high concentrated cellulose/1-ethyl-3-methylimidazolium diethyl phosphate with and without DMSO to improve the alignment of cellulose chains (figure 1 left). The results showed that by increasing of the cellulose concentration from 7.6 to 12.4 wt $\%$, the solution texture changed from completely isotropic to weakly nematic. Further increase of the cellulose concentration resulted in higher regularity of the alignment of the fibers. Cellulose fibers obtained from IL solution containing 18.0 wt. \% of cellulose possess the highest molecular alignment, and therefore, these fibers exhibited a Young's modulus up to $22 \mathrm{GPa}$ together with a moderately high tensile strength of $305 \mathrm{MPa}$. SEM study established that the fibers showed circular, dense and homogeneous cross sections, without any visible voids as shown in figure $1 \mathrm{right}$ 33 . 

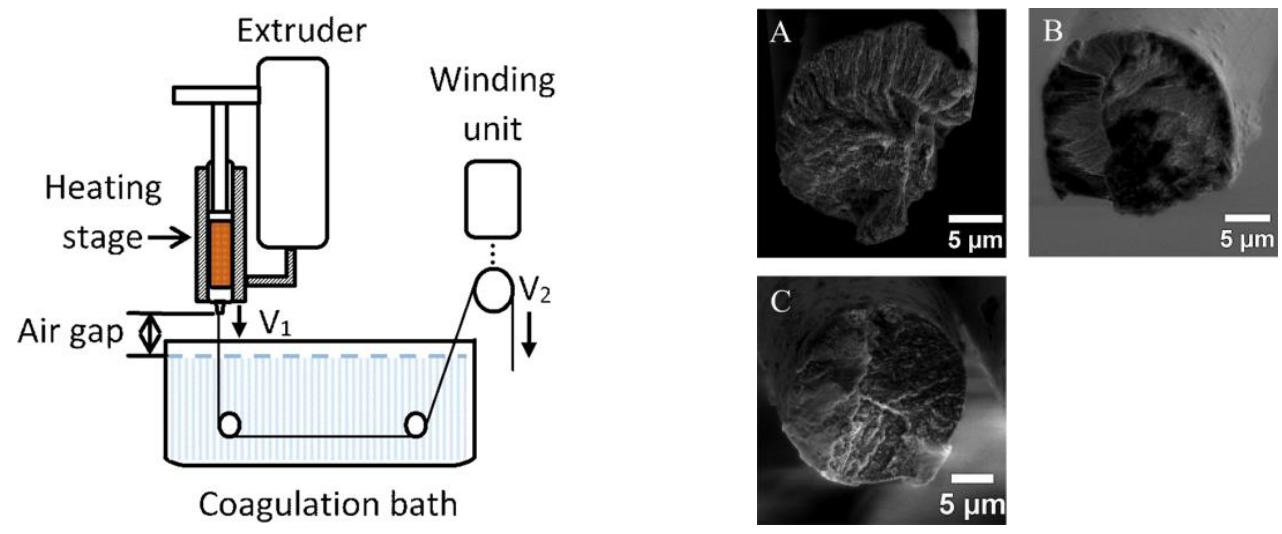

Figure 1 left: Schematic of dry-jet wet fiber spinning technique for cellulose fiber; right: SEM images of cross sections of (A) 12.4, (B) 15.2, and (C) $18.0 \mathrm{wt} \%$ cellulose fibers fractured using liquid nitrogen. Reprinted with permission from Zhu et al. ${ }^{33}$, American Chemical Society, Copyright 2016.

Electrospinning of cellulose and its composites using ionic liquid as spinning solvent has been investigated for the fabrication of nanofibrous materials with high specific surface areas, controllable compositions, and high porosities ${ }^{35}$. These materials have potential for a wide range of applications ${ }^{36}$. Nonwoven mats of electrospun cellulose fibers are expected to be utilized in several applications such as ultrafiltration, tissue engineering, catalysis, solar cells, sensors, and batteries ${ }^{37}$. In the field of biopolymer spinning, cellulose is dissolved in appropriate ionic liquids and then spun into a water bath. An early study investigated the preparation of nonwoven fibers of cellulose by electrospinning in $\left[\mathrm{C}_{4} \mathrm{mim}\right] \mathrm{Cl}$.

Spinning using ionic liquids can be processed with wet spinning or by dry-jet wet spinning, allowing controlling the properties of the fibers. 1-butyl-3methylimidazolium chloride $\left[\mathrm{C}_{4} \mathrm{mim}\right] \mathrm{Cl}$ was applied for realization of spinning dopes that contained up to $16.5 \%$ cellulose dopes. Moreover, $\left[\mathrm{C}_{2} \mathrm{mim}\right] \mathrm{OAc}$ was investigated for wet spinning of cellulose. The study focused on the rheology of the spinning dopes, characterization of the fiber and recycling the $\mathrm{IL}^{29}$.

All these findings highlight that ease availability of cellulose fibers via IL-based spinning techniques. As a further development, carbonization of these cellulose fibers has been investigated to access carbon fibers. However, following conventional approaches, the presence of impurities like lignin and hemicellulose and the porous structure hamper the use of cellulose for production of carbon fibers. On the opposite, 
cellulosic fibers produced through IL technologies possess well-defined fiber diameters and high purity. As a result, these fibers are suitable precursor materials for the production of carbon fibers. For example, cellulose fibers were prepared via phosphorylation of cellulose with the ionic liquid through dry-wet-spinning process. The prepared fibers were carbonized at different temperatures (figure 2). The study showed that preparation of carbon fibers in high carbonization yields could be controlled by adjusting degree of substitution ${ }^{36}$. It highlights the importance of both cellulose processing and derivatization for the formation of functional carbonaceous materials
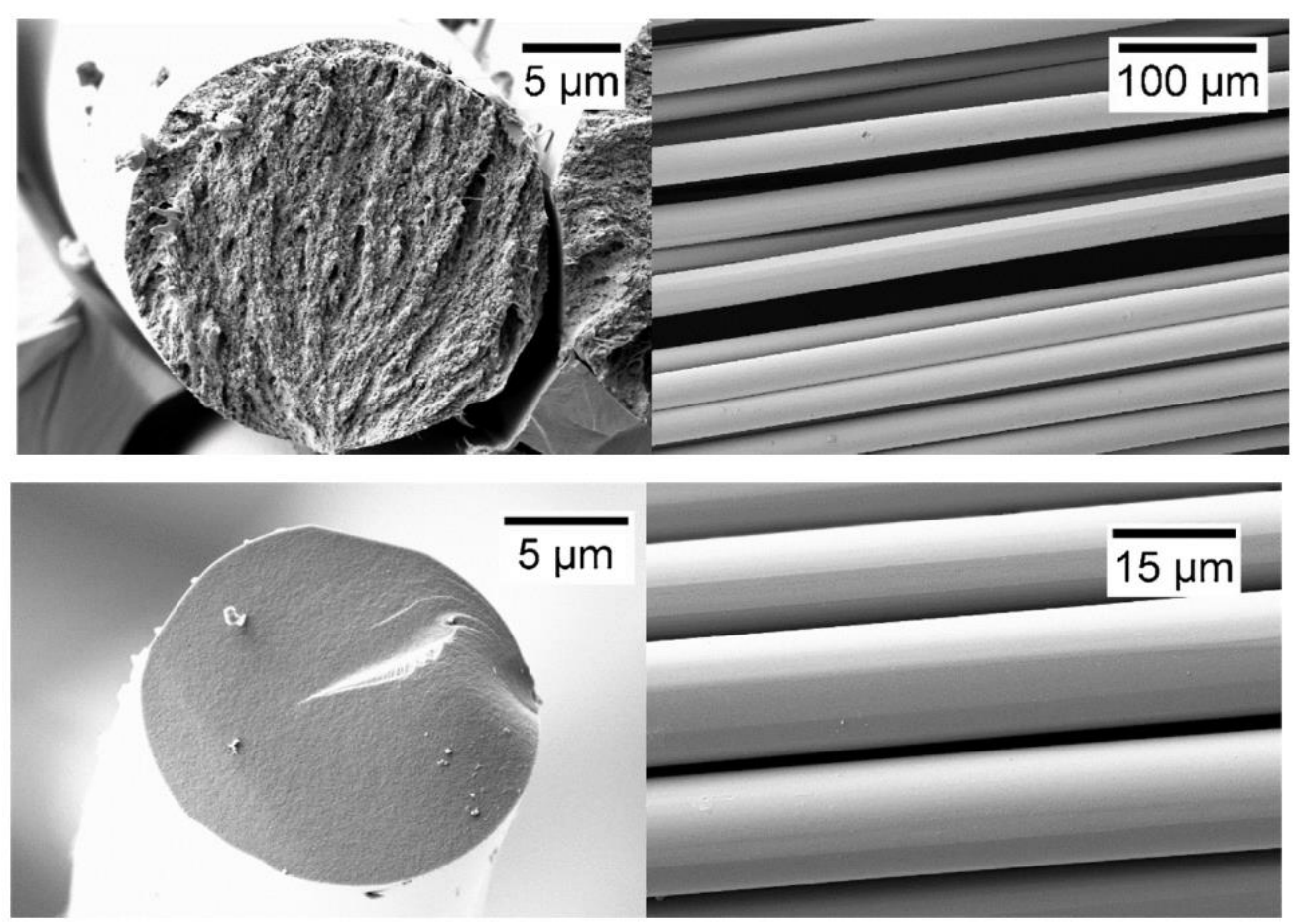

Figure 2: SEM of cellulose phosphonate fibers (top) and cellulose phosphonate based carbon fibers at $1400{ }^{\circ} \mathrm{C}$. Reprinted with permission from Spörl et al. ${ }^{38}$, Elsevier, Copyright 2016.

Moreover, ILs assist the addition of cellulose to the most common polymers used for preparing carbon fibers, poly(acrylonitrile) (PAN), for preparing economic and environmentally friendly alternatives to conventional carbon fibers precursors. The results suggest that the incorporation of the cellulose impacts the thermal transition temperatures of PAN. The use of both polysaccharides blended with poly(acrylonitrile) 
and ionic liquids as the co-solvent presents as an sustainable approach to the expansion of novel carbon fibers ${ }^{39}$.

\section{New cellulose derivatives: chemical modification of cellulose in Ionic liquids}

Ionic liquids are efficient solvents for preparing novel polysaccharide derivatives via chemical modification reactions. We used chemical modification of chitosan in IL media for accessing guanylated chitosan derivatives ${ }^{40}$. Moreover, homogeneous cellulose solutions in ILs have been used for the synthesis of various cellulose derivatives, mainly esters of organic and inorganic acids. For example, the p-toluene sulfonic acid ester of cellulose, tosyl cellulose, is a useful intermediate for the preparation of various cellulose derivatives ${ }^{41}$. The homogeneous tosylation allows controlling the degree of substitution and uniform distribution of tosyl moieties along the cellulose chain. Gericke et al. studied the preparation of tosyl cellulose in ionic liquids in the presence different co-solvents. The effects of reaction parameters on the degree of substitution with tosyl- and 6-chloro-6-deoxy groups as well as on the molecular weight were studied to lead to intermediate products for subsequent conversion into different cellulose derivatives ${ }^{42}$. As the tosyl moiety is an excellent leaving group in nucleophilic substitution reactions, it can be substituted by various nucleophiles such as halides, pseudo-halides (azide, thiocyanate,...) and amines to access novel 6-deoxy-6-functionalized cellulose derivatives ${ }^{42}$. Nucleophilic substitution reactions with activated cellulose are therefore useful for the preparation of new biomaterials. As an example, new amino-functionalized yields with regioselective substitution could also be obtained from 6-deoxy-6-bromo-cellulose ${ }^{43}$.

Cellulose carbonates are another important class of intermediates that gain increasing interest in the syntheses of functional cellulose materials. In two-step sequences, cellulose phenyl carbonates were first obtained from neat cellulose with phenyl chloroor fluoroformates. These intermediates undergo selective aminolysis with primary amines to yield a variety of soluble cellulose carbamates ${ }^{18,44}$. In this way, cellulose tricarbonates were synthesized from cellulose and phenyl chloroformate in a mixture of 1-butyl-3-methylimidazolium chloride/pyridine as reaction medium. The phenyl chloroformate reagent is inert in the solvent mixture, as shown in scheme $1^{18}$. The aminolysis of the highly substituted cellulose phenyl carbonates produces cellulose 
carbamates with a high density of functional groups (DS 3) that might be applied in the chemistry of polyelectrolytes.
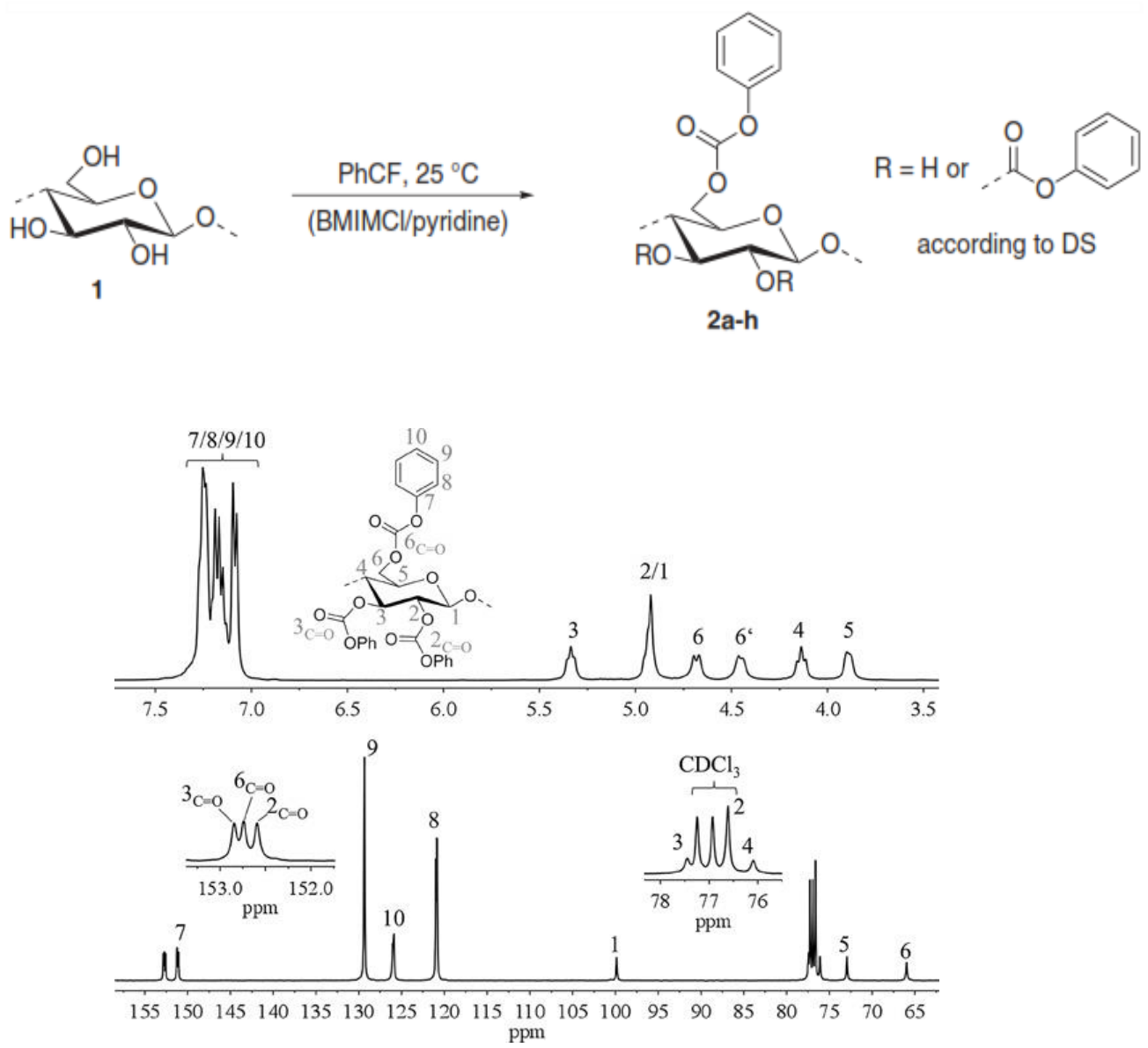

Scheme 1: Reaction scheme of the synthesis of cellulose phenyl carbonate; PhCF: Phenyl chloroformate; $\left[\mathrm{C}_{4} \mathrm{mim}\right][\mathrm{Cl}]$ :1-Butyl-3-methylimidazolium chloride accompanied with ${ }^{1} \mathrm{H}$ and ${ }^{13} \mathrm{C}$ NMR spectra of PhCF. Reprinted with permission from Elschner et al. ${ }^{18}$, Wiley, Copyright 2014.

However, due to the difficulty associated with the use of chloroformates and fluoroformates, cellulose carbonates have also been obtained using less toxic substrates, in particular dimethyl and diethyl carbonate. Labafzadeh et al. reported cellulose dialkylcarbonates with a moderate degree of substitution (DS 1). The alkoxycarbonylation of cellulose was accomplished by applying dialkylcarbonates in the ionic liquid methyl trioctylphosphonium acetate or $\left[\mathrm{C}_{2} \mathrm{mim}\right] \mathrm{OAc}{ }^{45}$, often using DMSO as co-solvent. 
Another example for cellulose derivatization makes use of the couplings of amines with acetoacetyl compounds that produces enamines under mild reaction conditions. Cellulose acetoacetate with different degree of substitution have been synthesized under homogeneous conditions using the ionic liquid, 1-allyl-3-methylimidazolium chloride, as a solvent. Hexylamine, glutamic acid, cysteine, and tyramine were incorporated onto cellulose acetoacetate via the formation of enamine with the acetoacetyl to form different types of cellulose derivatives (hydrophobic, carboxyl, thiol and phenolic hydroxyl derivatives). This process provides a simple and ecofriendly modular for synthesize divers functional cellulose derivatives as shown in scheme $2^{46}$.

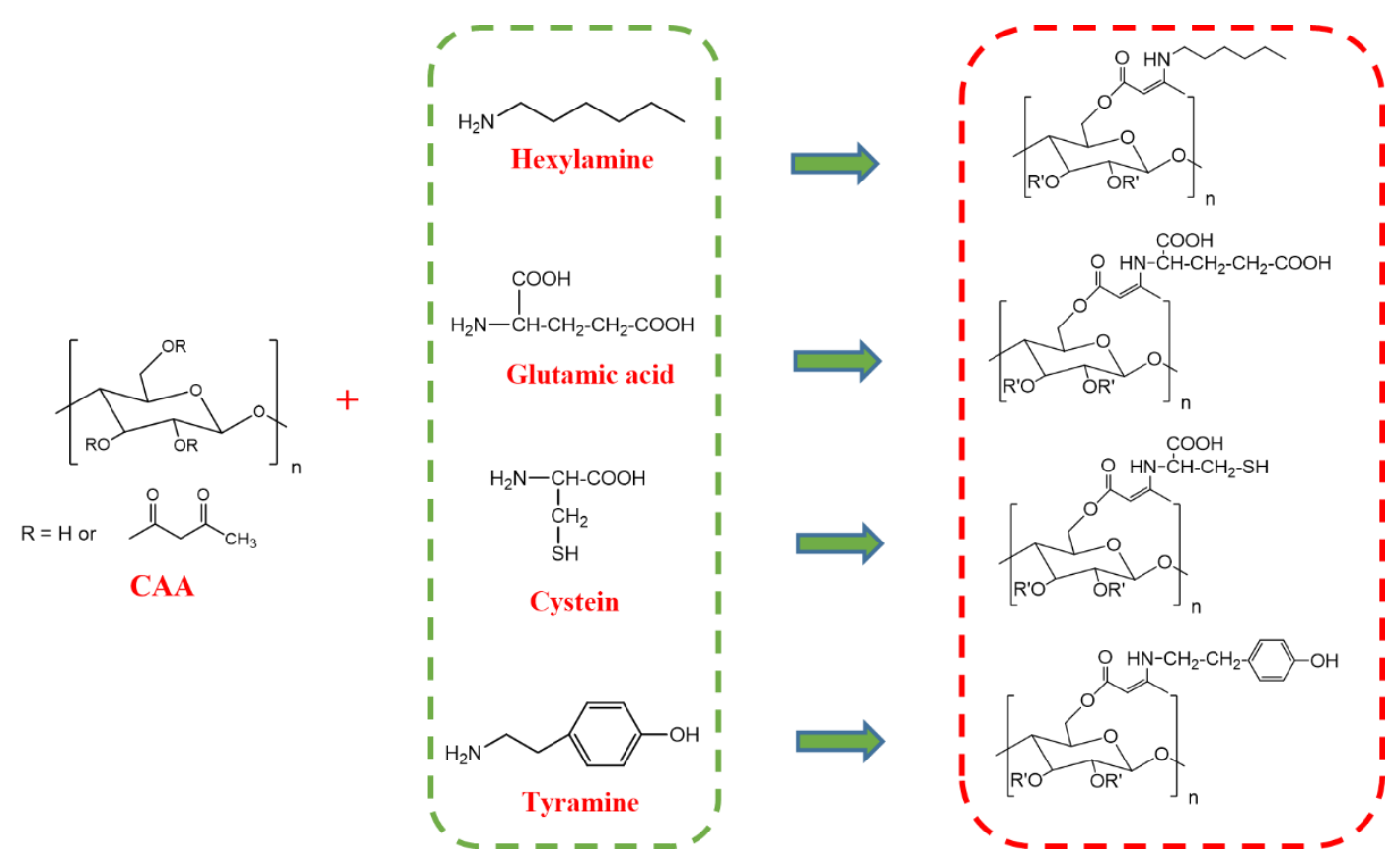

Scheme 2 Schematic illustration for the formation of enamine bond from cellulose acetoacetate and various amino compounds. Adapted with permission from Liu et al. ${ }^{46}$, Elsevier, Copyright 2017.

Besides these modifications with small functional groups, the elaboration of amphiphilic cellulose based graft copolymers attracted considerable interest. These polymers consisting of a cellulose backbone combined with grafted polymer side chains display interesting self-assembly behavior and allow accessing smart nanoparticle systems that are particularly useful for drug vectorization via encapsulation. Ionic liquids are particularly suitable media for grafting reactions onto cellulose. For 
example, Guo et al. reported cellulose-graft-poly(e-caprolactone)s via homogeneous ring-opening polymerization (ROP) of $\varepsilon$-caprolactone onto neat cellulose ${ }^{47}$. The grafting reaction occurs smoothly in ionic liquids such as $\left[\mathrm{C}_{4} \mathrm{mim}\right] \mathrm{Cl}$. The molecular architecture of the copolymers can be controlled via the grafting reaction conditions, i.e. by selecting different catalysts, reaction temperatures and cellulose/ $\varepsilon$-caprolactone feed ratios. The self-assembly of the cellulose-graft-poly( $\varepsilon$-caprolactone) copolymers resulted in the formation of nanomicelles of defined size with a cellulose core and a poly( $\varepsilon$-caprolactone) outer layer ${ }^{47}$. In the following, Zuppolini et al. recently reported the preparation of amphiphilic nanoparticles made of cellulose-graft-poly $(\varepsilon-$ caprolactone) through electrospraying. The formed round-shaped particles were used for controlled delivery of hydrophilic drugs such as sodium diclofenac ${ }^{48}$. Another example of cellulose based graft copolymers was reported by Guo et al., who synthesized a series of microcrystalline cellulose-graft-poly(lactide) copolymers displaying various structural features ${ }^{49}$. The copolymer architecture was controlled in terms of grafting ratio, hydrophobic chain length, and molecular weight. Once more, the solvent of choice to access these copolymers was $\left[\mathrm{C}_{4} \mathrm{mim}\right] \mathrm{Cl}$. The copolymers selfassemble in aqueous media to form spherical nanomicelles with diameters in the range of 10-50 $\mathrm{nm}$. Moreover, the hydrophobic antitumor drug paclitaxel (PTX) was efficiently encapsulated: the copolymers showed high encapsulation efficiency and loading content of $89.30 \%(\mathrm{w} / \mathrm{w})$ and $4.97 \%$, respectively ${ }^{49}$. All these examples highlight the interesting self-assembly behavior of cellulose-based biodegradable amphiphilic copolymers, together with their high potential as nanocarriers for biomedical applications.

\section{Cellulose based ionogels, blends and composites: towards functional materials}

For the elaboration of functional materials with desired and controlled properties, the combination of various components is often required. The simplest way to combine various functional materials or phases consists in mixing two or more compounds. So far, this approach is rather limited due to the low solubility in common solvents, but once again, IL processing opens new possibilities to access cellulose based di- or multicomponent materials for applications in various domains. This chapter summarizes various recent approaches for the synthesis of these composite materials. 


\section{Gel polymers or electrolytes}

Cellulose based materials recently attracted great interest in the energy sector. Due to the polyvalence of cellulose and the possibility to form cellulose based materials with various structures and surface chemical properties, these materials found applications in a number of energy storage devices including supercapacitors, lithium-ion batteries, lithium-sulfur batteries, and sodium-ion batteries ${ }^{50}$. More specifically, cellulose/IL gels appear as promising solid electrolytes ${ }^{51}$.

Polymer electrolytes, in particular polymer gel electrolytes, offer a promising way to reduce the disadvantages of liquid electrolytes. Gel polymer electrolytes are formed by the incorporation of liquid electrolytes, e.g. ionic liquids, within a polymer membrane matrix ${ }^{52}$. As a result, this approach combines the advantages of the high ionic conductivity of liquid electrolytes with the good processability and increased mechanical properties of polymers. Gel polymer electrolytes display highly promising features, such as a wide electrochemical window, high thermal stability and good compatibility with electrodes. Cellulose is currently intensively studied as polymer matrix for gel polymer electrolytes for the fabrication of lithium-ion batteries. However, biopolymer-based membranes have the disadvantage of low porosity or large pore diameter, which would reduce the electrochemical performance of the resulting gel polymer electrolytes. The low porosity of biopolymers reduces the adsorption of liquid electrolytes and consequently decreases the ionic conductivity and electrochemical performance of the produced lithium ion batteries. Nonvolatile electrolytes, such as ionic liquids, are investigated to improve lithium battery safety and oftenmatch or outperform the current the carbonate electrolytes used in lithium ion batteries. Recent trails for preparing gel polymer electrolytes were carried out using ionic liquids and cellulose ${ }^{53}$. The advantages of gel electrolytes present them to be used alone or with lithium ion conducting ceramics, in composites or sandwiched between the lithium ion conducting ceramics and the electrodes. Encapsulating a liquid electrolyte in a gelating material, such as a polymer, is a promising technique for preparing gel electrolytes ${ }^{54}$. The produced gel electrolytes by this method is a solid, but the entrapped liquid often keeps its fluid performance, especially at high concentrations ( $>70 \mathrm{wt} .-\%$ liquid).

Cellulose nanofibers have been used as paper-derived separators with a nanoporous structure. These materials display electrochemical safety, negligible thermal shrinkage, 
and a strong affinity for liquid electrolyte. Moreover, cellulose derivatives showed good affinity toward liquid electrolytes. Wan et al. studied the preparation of cellulose aerogel membranes from a cellulose-ionic liquid solution via a dissolution-regeneration-supercritical drying route ${ }^{55}$. These membranes exhibited fast absorption and gelation when exposed to liquid electrolyte, and the gelled membranes showed ionic conductivity and consequently excellent electrochemical stability and battery performance. Room temperature ionic liquids have been explored in ionogels for energy storage applications. For example, an ionogel was prepared using methyl cellulose in the solvate ionic liquid $[\mathrm{G} 4 \mathrm{Li}]^{+}[\mathrm{TFSI}]^{-}$with $90 \mathrm{wt} \%$ liquid. This ionogel exhibited $5 \mathrm{~V}$ anodic stability, ionic conductivity of $4 \times 10^{-4} \mathrm{~S} / \mathrm{cm}$ ionic conductivity, high storage modulus, $\mathrm{E}^{\prime}=60 \mathrm{MPa}$ and thermal stability up to $200{ }^{\circ} \mathrm{C}$. The high room temperature conductivity and storage modulus of this ionogel is due to the semicrystalline fibrillar network formed by methyl cellulose ${ }^{56}$.

The fabrication of electrolytes is the most important challenge for preparing dyesensitized solar cells. Hydroxypropyl cellulose (HPC) and 1-methyl-3propylimidazolium iodide were used for the preparation of non-volatile gel polymer electrolyte for dye-sensitized solar cell. The incorporation of $100 \mathrm{wt}$. \% of 1-methyl-3propylimidazolium iodide, that is equal weights of HPC and IL, allowed reaching a material displaying an ionic conductivity of $7.37 \times 10^{-3} \mathrm{~S} / \mathrm{cm}^{57}$.

All these examples take benefit from the compatibility of ionic liquids and cellulose. Cellulose/IL ionogels can be obtained simply by solubilizing cellulose in IL media. These mechanically more robust phases display interesting ion-conduction properties due to the presence of ionic liquids. The direct combination of cellulose and ionic liquids in these ionogels is the simplest and most straightforward way for the elaboration of functional cellulose based phases with huge potential for energy storage. Cellulose/IL solutions can also be used to access cellulose hydrogels. Satani et al. prepared cellulose hydrogels by using an ionic liquid/DMSO mixed solution. Immersing the cellulose solution in a mold containing deionized water caused solvent replacement of the $\left[\mathrm{C}_{4} \mathrm{mim}\right] \mathrm{OAc} / \mathrm{DMSO}$ with deionized water. The pore size, water content and mechanical strength of the cellulose hydrogel were strongly affected by cellulose concentration ${ }^{58}$. Moreover, cellulose based conductive hydrogel prepared in ionic liquid displayed relatively high electrical conductivity, up to $7.83 \times 10^{-3} \mathrm{~S} / \mathrm{cm}$. The mechanical property of cellulose/polypyrrole hydrogel was enhanced compared to the pure cellulose hydrogel. Ionic liquids assist the combining the cellulose with the 
conductive polymer for producing special kind of hydrogels with unique properties and promising in various applications associated with biological and semiconducting materials ${ }^{59}$.

\section{Ionic liquid assisted adsorption of functional molecules on cellulose}

As indicated before, functional molecules show an important role in the development of high-performance functional composite materials, and we recently emphasized that modified chitosan/silica hybrid materials are efficient adsorbents for various types of organic compounds ${ }^{60,61}$. Ionic liquids emerged as promising solvents in the development of high-added values materials such as functional biopolymers. For example, ionic liquids were used to immobilize stimuli responsive molecules, such as photochromic molecules, onto biopolymers. These materials have high thermal stability, rapid and reversible molecular switching and have been applied in devices such as actuators, photo-optical switches, optical memory, and displays ${ }^{62}$. Stimuliresponsive chromic paper devices were fabricated by supporting [ $\left.\mathrm{C}_{4} \mathrm{mim}\right]$-based ionic liquids on cellulose pulp fibers and consequently the supported ionic liquid was used as a layer for dissolving photochromic diarylethene (figure 3). Koga et al. supported diarylethene/[C $\left.\mathrm{C}_{4} \mathrm{mim}\right] \mathrm{NTf}_{2}$ on cellulose fibers within the paper, through hydrogen bonding between $\left[\mathrm{C}_{4} \mathrm{mim}\right]$ cations and hydroxyl groups of cellulose. The composites show rapid, uniform, and vivid coloration/decoloration upon UV/visible light irradiation ${ }^{34}$.

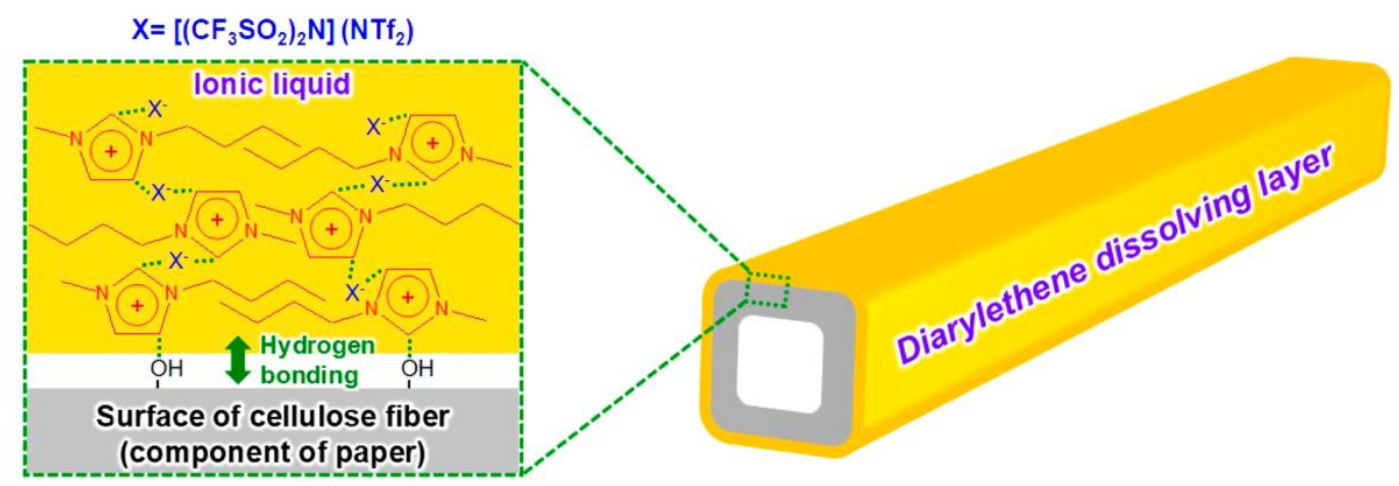

Figure 3 Schematic representation of the supported ionic liquid $\left[\mathrm{C}_{4} \mathrm{mim}\right] \mathrm{NTf}_{2}$ as a dissolving layer for photochromic diarylethene on cellulose pulp fibers. Reprinted with permission from Koga et al. ${ }^{34}$, American Chemical Society, Copyright 2017. 
Supporting the ionic liquids on cellulose fibers was achieved by room temperature solution processes. The supported ionic liquid could in turn support dissolved diarylethene on the cellulose fibers of the paper. As proof-of-concept, the as-prepared paper device exhibited excellent photochromic performance with respect to color uniformity and vividness, which were significantly better compared to those of the paper device prepared without ionic liquids. The nonvolatile ionic liquid ensured that the excellent photochromic performance remained largely unchanged over at least 5 years.

\section{Formation of cellulose based bio-blends via ionic liquid processing.}

Cellulose-reinforced blends show increasing importance for lightweight construction and progressively replace traditional materials. Due to its nontoxicity, biocompatibility, and renewability, cellulose represents a sustainable alternative to synthetic polymers. In this context, ionic liquids allow the straightforward preparation of sustainable blends with good mechanical properties. For example, Berton et al. reported the formation of hydrogels from high molecular weight chitin and cellulose rich materials through repeated dissolution of the original biomass in 1-ethyl-3-methylimidazolium acetate. These hydrogels were obtained by gelation or casting, and could further be processed to aerogels via washing procedures, to produce materials of low density, high porosity, favorable compressibility and high water uptake ability ${ }^{64}$. When ionic liquids were used to produce biopolymers films, the formed films are homogeneous and show good processability.

Ionic liquids can assist hydrogel formation through dissolution, physical or chemical cross-linking. Physical cross-linking involves various weak interactions such as chain entanglements, van der Waals forces, hydrogen bonding, crystallite associations, and/or ionic interactions. Chemical cross-linking originates from covalent bonds between polymeric chains or between the polymer(s) and a cross-linker added the polymer solution ${ }^{65-67}$. For example, in the field of hydrogels and drug delivery, cellulose and chitin are elastic materials and retain diffusive properties identical to those of a liquid. Biopolymer-based hydrogels can absorb and release water or biological fluids in a reversible and non-irritating manner, suggesting high biocompatibility towards living tissues. Ionic liquids can serve as suitable media for the preparation of both stable physical and chemical hydrogels ${ }^{68}$. 
The distinctive properties of chitosan arising from the presence of $\mathrm{NH}_{2}$ groups, blends from cellulose and chitosan are promising systems for creating new polymeric materials with improved properties. ILs permit the production of chitin-cellulose and chitosancellulose fiber blend through electrospinning. For example, Mundsinger et al. suggested a method for the preparation of cellulose-chitin blend fibers through dissolving chitin and cellulose in 1-ethyl-3-methylimidazolium propionate ${ }^{69}$. The obtained multifilament fibers by a continuous wet-spinning process showed enhanced water retention capacity compared to pure cellulose fiber.

Due to the increasing demand for recyclable and sustainable composites, cellulose fibers are intensively applied in biocomposites and natural fiber reinforced plastic. The properties of the composites depend on the matrix, the reinforcing fiber and the interface. Dissolving cellulose in suitable ILs for the preparation of cellulose fiberreinforced pre-composite was found to be a suitable strategy to overcome the drawbacks associated with these types of composites such as low mechanical strength and weak adhesion between hydrophobic polymer and hydrophilic fibers ${ }^{30}$.

In order to fabricate films with improved bioactivity, blends produced from cellulose and proteins may mimic the naturally formed environment of certain tissues. Therefore, ionic liquids were applied as green media for preparing new cellulose/protein blends. For example, natural wool from merino sheep was dissolved in $\left[\mathrm{C}_{4} \mathrm{mim}\right] \mathrm{Cl}$ and the solution was applied to prepare wool/cellulose acetate blends. Blending with cellulose acetate increases the glass transition temperature and therefore enhances the thermal stability compared to neat polymers. The formed blends exhibit homogeneous surface morphology arising from strong intermolecular hydrogen bonding between regenerated wool and cellulose acetate ${ }^{70}$. In another study, cellulose and keratin from three different sources (wool, hair and chicken feather) were synthesized in a simple one-step method using once more $\left[\mathrm{C}_{4} \mathrm{mim}\right] \mathrm{Cl}$ as solvent. The results showed that the formed blends were homogeneous, and keratin preserved in a certain extent its secondary structure in the formed composites. Moreover, the combination of cellulose and keratin improves the mechanical properties of the composites. Also, the antimicrobial properties is due to the protein and the type of keratin. These cellulose/wool keratin composites can be applied for drug delivery and wound dressing. The release kinetics can be controlled by altering the concentration of wool keratin in the composite. The antibacterial activity against methicillin depends on the type of the keratin, namely, the bactericidal effect is the strongest for feather and the weakest for wool ${ }^{71}$. Moreover, 
reinforcing cellulose fibers with protein was found to increase the bioactivity of the formed blends.

Silk fibroin recently emerged as a promising candidate for electronic implants interfaced with the human body because it has the ability to entrap or stabilize chemical or biologically active molecules, thus allowing the addition of a new function for the blend. The regeneration of cellulose/silk-, chitin/silk-, and chitosan/silk-based blends after dissolution in ionic liquid 1-allyl-3-methylimidazolium chloride followed by precipitation in water were studied through simulation with theoretical modeling and molecular dynamics ${ }^{72}$. The authors showed that silk affects the properties of the regenerated biocomposite with respect to their $\beta$-sheet crystallinity, morphology, thermal stability, and Young's modulus. It is clear from this study that the structure and properties of the prepared biocomposites can be adjusted by using different solvents and alternative processing procedures, thus opening a large playground for materials design. Another study reported the preparation of cellulose and silk blends with different ratios using ionic liquid as a comment solvent. The formed scaffold was applied as a potent stimulator of MSC chondrogenic maturation independent of any chondrogenic growth factor stimulation ${ }^{73}$. Finally, cellulose/silk blends also have potential for applications as solid electrolytes, in particular for the elaboration of polysaccharide-protein bio-electrolyte ${ }^{74}$.

These examples show that purely organic cellulose based blends can be obtained via ionic liquid processing. Cellulose can be combined with various biopolymers, particularly proteins such as wool, silk and keratin. The resulting blends are completely biocompatible and have large potential especially for biomedical applications.

\section{Formation of cellulose based composites using ionic liquids.}

The incorporation of inorganic fillers into polymer matrices is a common strategy to enhance the mechanical properties of the resulting composite materials. Various fillers such as calcium phosphate ${ }^{75}$, metal oxides ${ }^{76,77}$, nanoclays ${ }^{78}$ and carbon nanotubes ${ }^{79}$ enhance the thermal, physical and mechanical properties of regenerated cellulose. Polysaccharide/inorganic hybrid materials were recently reported as efficient materials for different applications ${ }^{80,81}$, in particular for adsorption. In this context, we recently reported that guanylated chitosan is a particularly promising material to induce calcium phosphate mineralization ${ }^{80}$. 
For designing unique organic/inorganic bio composite materials, ionic liquids can be used as solvent for both biopolymers and inorganic precursors in a one-pot approach. In this context, it should be pointed out that mineralization and materials' formation in IL media often lead to inorganic materials that cannot be obtained via conventional approaches ${ }^{82-86}$. ILs are distinctive reaction media for the precipitation of inorganic materials in the presence of biopolymers.

For example, calcium phosphate mineralization was achieved from a cellulose solution in 1-butyl-3-methylimidazolium chloride, $\left[\mathrm{C}_{4} \mathrm{mim}\right] \mathrm{Cl}$. Different crystal phases from calcium phosphate were formed. The results show that homogenous cellulose/chlorapatite, or cellulose/monetite composites could be obtained by precipitation ${ }^{87}$. Besides these approaches, ILs also allow incorporating inorganic materials into cellulose fibers to access homogenous and hierarchical cellulose/inorganic hybrids. Ma et al. prepared cellulose/CaCO 3 nanocomposites using microwave-assisted ionic liquid method ${ }^{88}$. The authors studied the effect of cellulose concentration onto the morphology of the formed calcium carbonate and the results showed that the morphologies of $\mathrm{CaCO}_{3}$ changed from polyhedral to cube to particle with increasing cellulose concentration. Cytotoxicity results demonstrated that the cellulose $/ \mathrm{CaCO}_{3}$ nanocomposites had a degree of biocompatibility and is promising for the biomedical applications. Moreover, ionic liquids assist the preparation of bioactive blends from natural polymers. For example, cellulose and wool were blended by combination of the two polymers from $\left[\mathrm{C}_{4} \mathrm{mim}\right] \mathrm{Cl}$. The formed blend exhibited bioactivity towards growth of crystalline hydroxyapatite particles with a uniform size, shape and dimension ${ }^{89}$.

Hao et al. prepared new adsorbents for $\mathrm{Ce}(\mathrm{III})$ adsorption by mixing graphene oxide (GO) and cellulose in $\left[\mathrm{C}_{4} \mathrm{mim}\right] \mathrm{Cl}^{63}$. The SEM image of graphene oxide showed a typical lamellar structure while regenerated cellulose exhibited a compact structure. The cellulose/graphene oxide composite film shows homogeneous morphology and no rough interface was observed (figure 4). The nanocomposite showed promising properties in adsorption, as the maximum adsorption capacity of $\mathrm{Ce}$ (III) reached 109.1 $\mathrm{mg} \mathrm{g}^{-1}$. 

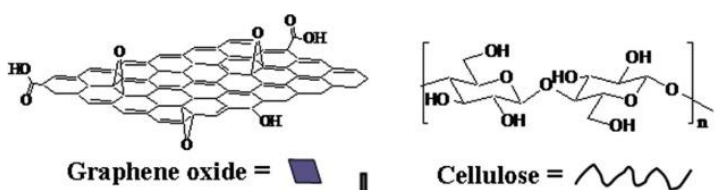

Graphene oxide $=\square$
$60^{\circ} \mathrm{C}$, ultrafomic

Cellulose $=\curvearrowright$

[Bmim]Cl

treated

$100^{\circ} \mathrm{C}$, stirring

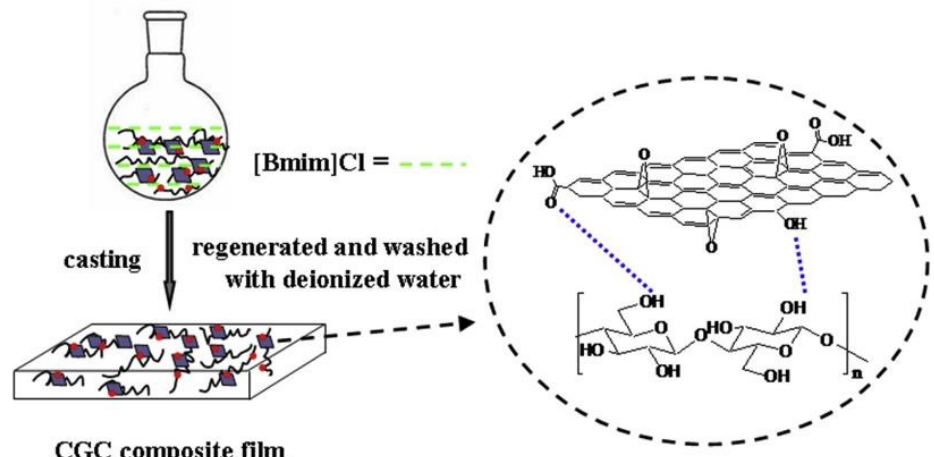

CGC composite film

Adsorption groups $=$ the oxygen atoms of the carboxyl and hydroxyl groups

.... Hydrogen bonds between $\mathrm{GO}$ and cellulose

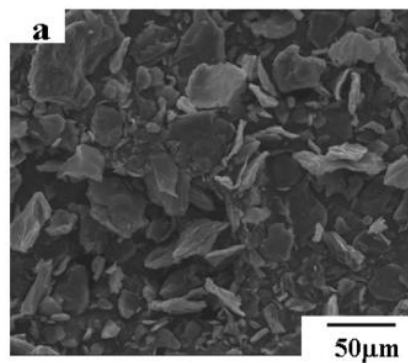

b
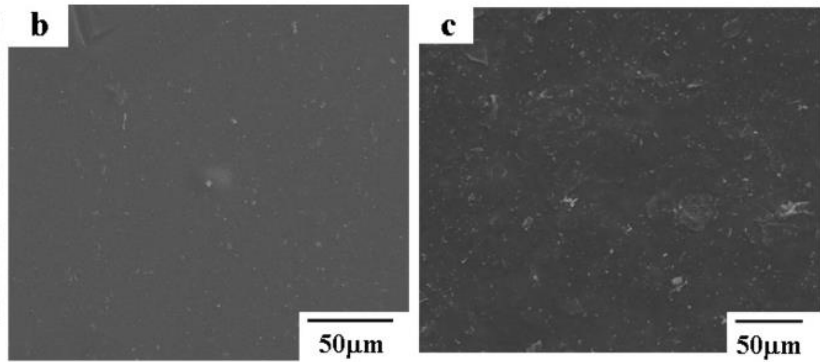

Figure 4 top: preparation route of regenerated cellulose/graphene oxide composite; bottom: SEM images of GO (a), regenerated cellulose (b) and regenerated cellulose/graphene oxide composite (c). Reprinted with permission from Hao et al. ${ }^{63}$, Elsevier, Copyright 2019.

In a different strategy, ionic liquids can act as a dispersing medium for increasing the homogeneity of biopolymers/inorganic composites. For example, Liu et al. reported conductive composite materials from multiwalled carbon nanotubes/graphene sheets/cellulose via an eco-friendly wet-spinning method. 1-Ethyl-3methylimidazolium diethyl phosphate was used as both solvent and dispersant. The prepared macropores and the double-layer structure composite showed a nearly perfect electrical double-layered structure. The maximum electrical conductivity of $1195 \mathrm{~S} / \mathrm{m}$ was achieved using a mass ratio of 2:3:1 of multiwalled carbon nanotubes-graphene sheets-cellulose fibers ${ }^{90}$. 
On the other side, nanocomposites may serve to improve the mechanical properties of cellulose. Mahmoudian et al. prepared new environmentally friendly nanocomposites by incorporation of montmorillonite into cellulose matrix using ionic liquid, $\left[\mathrm{C}_{4} \mathrm{mim}\right] \mathrm{Cl}$ as solvent by solution casting method. Incorporation of montmorillonite improved the thermal stability and char yield of regenerated cellulose. The tensile strength and Young's modulus of regenerated cellulose enhanced by $12 \%$ and $40 \%$, respectively, with the addition of $6 \mathrm{wt} . \%$ montmorillonite. Interestingly, these nanocomposite films displayed enhanced gas barrier properties and water absorption resistance ${ }^{76}$.

Peng et al. prepared magnetic cellulose-chitosan/iron oxide composite using ionic liquids as solvent for dissolution and regeneration. The formed composite was used for the immobilization of laccase. Immobilized laccase retained $88.9 \%$ activity after 12 reaction cycles ${ }^{91}$. In another study, the same authors reported that the magnetic cellulose-chitosan/iron oxide composite are efficient and re-usable systems for $\mathrm{Cu}$ (II) adsorption. The formed microspheres show porous structure, high surface area, and adsorption capacity, with a maximum adsorption capacity for $\mathrm{Cu}(\mathrm{II})$ of $65.8 \mathrm{mg} / \mathrm{g}{ }^{92}$. Porous magnetic cellulose $/ \mathrm{Fe}_{3} \mathrm{O}_{4}$ beads were synthesized by dispersing $\mathrm{Fe}_{3} \mathrm{O}_{4}$ magnetic particles into the matrix of the cellulose dissolved in ionic liquids and further modified with glutaric anhydride on cellulose. The resulting beads were employed as effective adsorbents for removal of methylene blue and rhodamine B from aqueous solution with adsorption capacities of 1186.8 and $151.8 \mathrm{mg} / \mathrm{g}$, respectively ${ }^{93}$. Aerogels are a class of light-weight (bulk density $0.003-0.2 \mathrm{~g} / \mathrm{cm}$ ) solid materials with a 3D network scaffold. Cellulose aerogels were recently obtained via formation of a cellulose suspension using a non-solvent followed by drying in adequate technique such as freeze-drying or supercritical drying with $\mathrm{CO}_{2}$. Cellulose based aerogels recently emerged as thermal super-insulating or flame retardant materials ${ }^{94,95}$.

Here, the combination of cellulose and silica can further enhance the thermal superinsulating efficiency. Cellulose-silica aerogel were prepared using 1-ethyl-3methylimidazolium acetate by forced-flow impregnation as opposed to impregnation driven by molecular diffusion method (figure 5). The prepared aerogels showed thermal conductivity lower than that of the neat aerocellulose and very close to the conductivity of air due to the formation of superinsulating mesoporous silica inside cellulose pores ${ }^{96}$. B. Yuan et al. prepared cellulose/silica composite aerogels via a two-step sol-gel technique in cellulose gel, which was regenerated from dissolved cotton pulp in 1-allyl- 
methylimidazole chloride ionic liquid. The composite aerogels with high silica content showed good transparency with light compared to neat cellulose aerogels. Moreover, the composite offered excellent flame retardant with enhanced mechanical performance as shown in figure $5^{97}$.
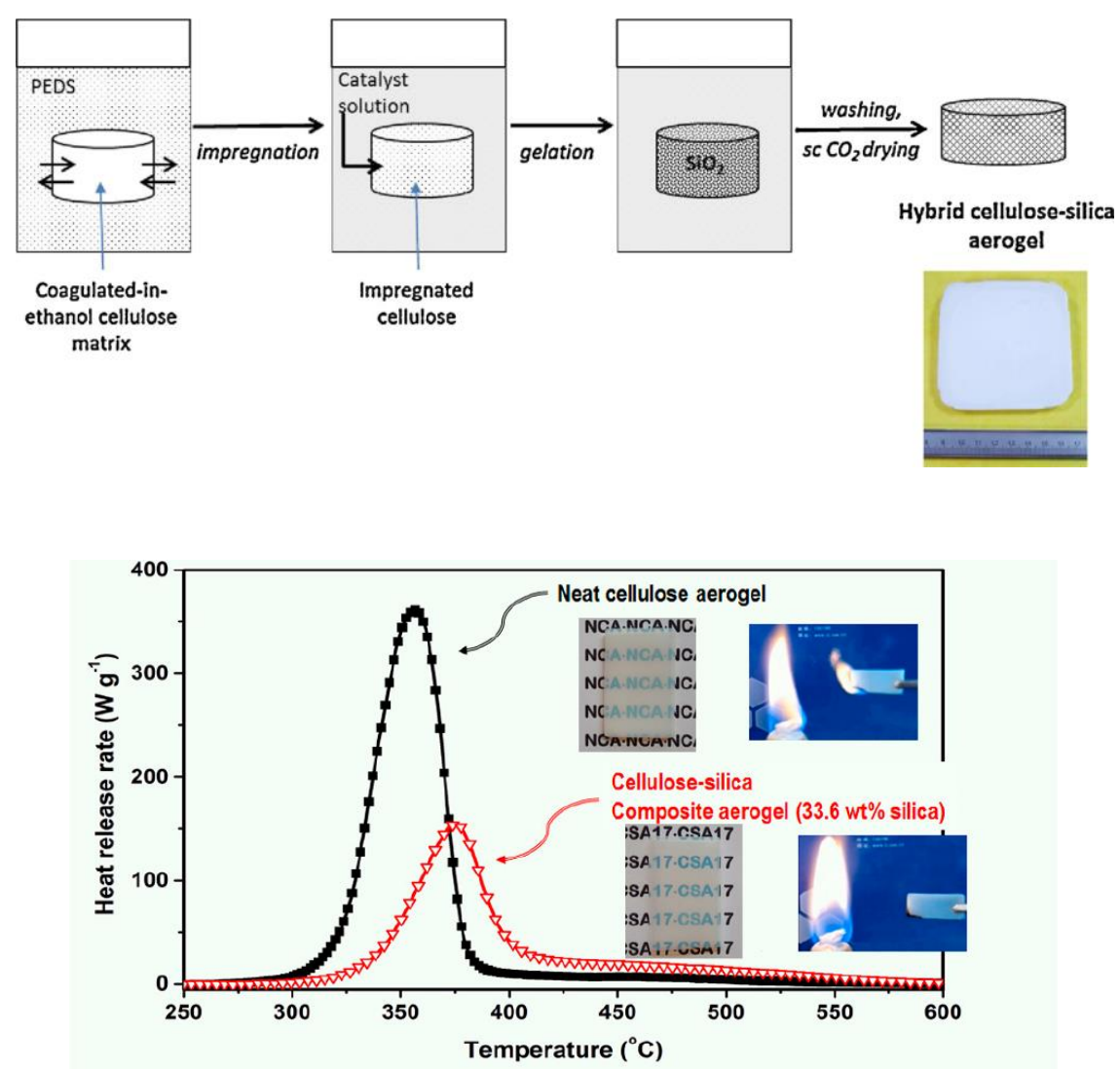

Figure 5 top: Schematic representation of the preparation route of cellulose-silica composite aerogels. Reprinted with permission from Demilcamps et al. ${ }^{96}$, Elsevier, Copyright 2015. Bottom: Heat release rate curves and photographs of cellulose/silica nanocomposite aerogels. Reprinted with permission from Yuan et al. ${ }^{97}$, American Chemical Society, Copyright 2017.

Cellulose as sustainable resource for the formation of molecular compounds: ILassisted cellulose depolymerization and degradation.

In the field of cellulose extraction, ionic liquids have attracted considerable interest as efficient solvents for delignification of lignocellulosic biomass and wood processing ${ }^{98}$. Significant differences appeared between the cellulose extracted by pulping and those extracted with ILs. The harsh conditions of pulping degrades the cellulose molecular weight due to the effect of chemicals, high temperatures, and extended treatment 
duration, thus resulting in chain scission and depolymerization ${ }^{99}$. This degradation can be reduced using IL extraction. The unique properties, particularly the high molecular weight, of cellulose obtained via IL extraction, allows the construction of various materials architectures such as fibers, films, and hydrogels ${ }^{64}$. It has been reported that 1-butyl-3-methylimidazolium chloride $\left[\mathrm{C}_{4} \mathrm{mim}\right][\mathrm{Cl}]$ can partially dissolve wood chips to separate cellulose from the IL solutions ${ }^{100}$. Another study reported that 1-allyl-3methylimidazolium chloride can extract cellulose from pine, poplar, Chinese parasol, and catalpa wood chips. The extracted fibers showed $85 \%$ cellulose content under optimized conditions ${ }^{101}$. Ionic liquid 1-ethyl-3-methylimidazolium acetate can effectively extract lignin from various lignocellulosic materials such as triticale, wheat straw and flax shives. Selective extraction of lignin by ILs is an effective method for the comprehensive application of lignocellulose. ${ }^{102}$.

On the other side, IL processing also allows the catalytic degradation of cellulose and controls the formation of molecular degradation products. In the field of cellulose hydrolysis for the preparation of molecular organic compounds, acidic ionic liquids exhibited higher catalytic activity compared to sulfonic acid ${ }^{103}$. Difunctional ionic liquids have been proposed with the methodology of individual functionalization of anion and cation for the hydrolysis of biopolymers. These acidic and hydrophobic ionic liquids can be synthesized by combining a hydrophobic cation with an acidic anion. A novel biphasic system consisting of water and an acidic and hydrophobic ionic liquid efficiently promotes cellulose hydrolysis to produce glucose ${ }^{104}$. Furthermore, Ionic liquids have been broadly applied as an efficient reaction media for the conversion of glucose or cellulose to 5-hydroxymethylfurfural ${ }^{105}$. These results show the high potential of IL processing of cellulose for the formation of molecular high value-added compounds. This approach is particularly appealing as the primary resource for these processes, cellulose, is abundant and cheap, and the IL can efficiently be recycled and re-used.

For example, Aid et al. showed that tungsten and molybdenum oxide-based polyoxometalates are able to decompose cellulose to carbohydrates such as glucose and mannose and a certain amount of glucose was also converted to 5hydroxymethylfurfural. The ability of the polyoxometalates to convert glucose to 5hydroxymethylfurfural remained $28.6 \%$ lower compared to the yield obtained with $\mathrm{CrCl}_{3}{ }^{106}$. In another work, the one-step conversion of cellulose to HMF (5hydroxymethylfurfural), an important renewable biofuel precursor and a useful 
building block, has been achieved in the presence of metal chlorides $\left(\mathrm{CrCl}_{3}, \mathrm{CuCl}_{2}\right.$, $\mathrm{SnCl}_{4}, \mathrm{WCl}_{6}$ ) in $\left[\mathrm{C}_{4} \mathrm{mim}\right] \mathrm{Cl}$ (scheme 3$)^{107}$. These trials highlight the ability of ionic liquids to dissolve high molecular weight cellulose and to promote controlled cellulose degradation reactions. These processes may yield high added-value molecular compounds and intermediates. This technology could represent new route for extracting biopolymers with unique properties significantly different from those extracted by traditional methods ${ }^{108}$. C. Chiappe et al. showed the degradation of microcrystalline cellulose in five ionic liquids using catalysts to form 5-hydroxymethylfurfural 109 (scheme 3).

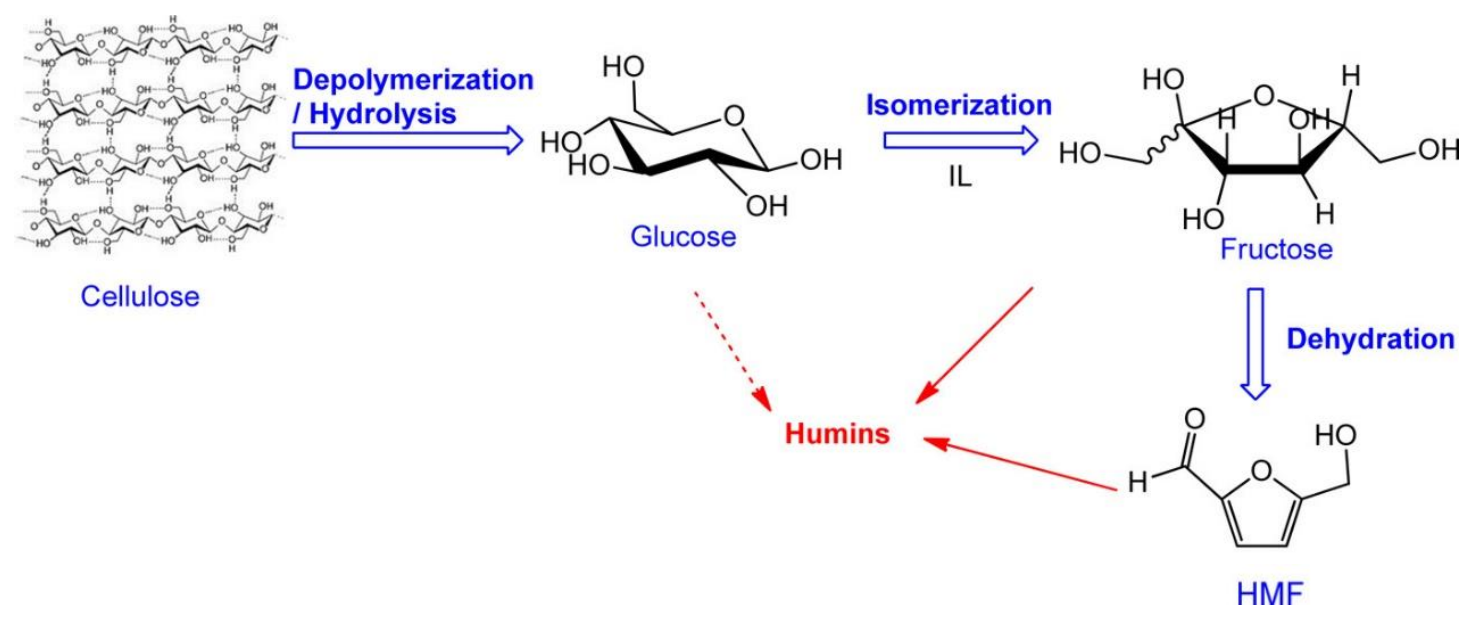

Scheme 3 Main steps for cellulose conversion into 5-hydroxymethylfurfural (HMF). Reprinted with permission from Chiappe et al. ${ }^{109}$, American Chemical Society, Copyright 2017.

The recovery of 5-hydroxymethylfurfural from ionic liquids is accompanied with very low extraction efficiency which limited the reusability of ionic liquids. The strong hydrogen bonding between the proton of the hydroxyl group of 5hydroxymethylfurfural and the $\mathrm{Cl}^{-}$anion of the $\left[\mathrm{C}_{4} \mathrm{mim}\right] \mathrm{Cl}$. A new strategy based on the solvent mediation has been suggested for enhanced 5-hydroxymethylfurfural extraction from a biphasic $\left[\mathrm{C}_{4} \mathrm{mim}\right] \mathrm{Cl} /$ methyl isobutyl ketone system, thus resulting in enhanced extraction efficiency ${ }^{105}$.

\section{Concluding remarks and future directions}

The IL-processing of cellulose has emerged as an interesting field with high potential for industrial applications. The current review focuses on the recent trends for 
dissolution and processing cellulose through ionic liquids. Several examples of materials, such as cellulose derivatives, composites, blends, and electrospun mats were studied using ILs as solvents. Table 1 gives an overview on the various strategies and derivatization techniques involving ILs. The hybridization of inorganics and cellulose has developed over the past few years in an attempt to understand the interactions between these hard inorganics and cellulose for constructing composites with unique properties and to prepare materials closer to humane bone. Moreover, achievement of composites with single component materials that combine the properties of inorganic materials with the flexibility and processability of cellulose chains will be breakthrough composites for biomedical applications especially tissue engineering ${ }^{87}$. The synthesis of such composites become more significant in planning multifunctional materials with complex domain structures. New approaches of cellulose-based composites are expected in the next several years as ionic liquids facilitate the use of cellulose. Dissolution of cellulose in ionic liquids represents a new technique to yield cellulose composites with improved mechanical properties. Using ionic liquids as appropriate solvents assisted the elaboration of various cellulose/protein membranes with controlled physical and chemical properties. The cellulose/protein blends are promising blends for in vitro tissue engineering. Moreover, it could be used as an implantable device for stimulating endogenous stem cells to initiate cartilage repair. In the field of electrochemistry, cellulose emerged as a good alternative for preparing polymer electrolytes used in various electrochemical applications such as dye-sensitized solar cell and lithium ion batteries. Cellulose based polymer electrolytes are incorporated in several devices for electrochemical applications due to good mechanical performance and stability. Moreover, the broad electrochemical window of ionic liquids suggests them as efficient solvent and reagents for preparing ionic electroactive polymer actuators.

Table 1: Overview on cellulose processing and derivatization in IL media.

\begin{tabular}{|c|c|c|c|c|c|}
\hline Cellulose source & Ionic liquids & Conditions & Products & Applications & Reference \\
\hline $\begin{array}{c}\text { Microcrystalline } \\
\text { cellulose }\end{array}$ & {$\left[\mathrm{C}_{4} \mathrm{mim}\right] \mathrm{Cl}$} & $\begin{array}{c}\text { IL/pyridine as reaction } \\
\text { medium }\end{array}$ & $\begin{array}{c}\text { Cellulose phenyl } \\
\text { tricarbonates }\end{array}$ & New cellulose derivative & 18 \\
\hline $\begin{array}{c}\text { Cellulose filter } \\
\text { paper }\end{array}$ & {$\left[\mathrm{C}_{4} \mathrm{mim}\right] \mathrm{NTf}_{2}$} & $\begin{array}{c}\text { Hydrogen bonding } \\
\text { between }\left[\mathrm{C}_{4} \text { mim }\right. \\
\text { cations and the } \\
\text { hydroxyl groups of } \\
\text { cellulose. }\end{array}$ & $\begin{array}{c}\text { High-performance composite } \\
\text { materials }\end{array}$ & $\begin{array}{c}\text { Paper-based } \\
\text { electrochromic device. }\end{array}$ & 34 \\
\hline Cellulose & $1,3-$ & $\begin{array}{c}\text { Dry-wet-spinning } \\
\text { process }\end{array}$ & $\begin{array}{c}\text { Carbon fibers in high } \\
\text { carbonization yields }\end{array}$ & & 38 \\
\hline
\end{tabular}




\begin{tabular}{|c|c|c|c|c|c|}
\hline & $\begin{array}{l}\text { m methyl-H- } \\
\text { phosphonate }\end{array}$ & & & & \\
\hline Cellulose pulp & $\begin{array}{l}{\left[\mathrm{C}_{4} \mathrm{mim}\right] \mathrm{Cl} \text { or }} \\
{[\mathrm{Amim}] \mathrm{Cl} \text { or }} \\
{\left[\mathrm{C}_{2} \mathrm{mim}\right] \mathrm{DEP}}\end{array}$ & $\begin{array}{c}\text { Tosylation in ionic } \\
\text { liquids and co-solvent }\end{array}$ & $\begin{array}{l}\text { Tosyl cellulose with different } \\
\text { DS values }\end{array}$ & $\begin{array}{l}\text { Nucleophilic displacement } \\
\text { reactions with tosyl } \\
\text { cellulose }\end{array}$ & 42 \\
\hline cellulose & $\begin{array}{c}\text { [P8881] } \\
\text { [OAc] } / \text { DMSO or } \\
{[\text { Emim] [OAc] }) .}\end{array}$ & $\begin{array}{c}\text { Homogeneous } \\
\text { alkoxycarbonylation } \\
\text { of cellulose }\end{array}$ & Cellulose Methylcarbonate & New cellulose derivative & 45 \\
\hline Cellulose & {$[\mathrm{Amim}] \mathrm{Cl}$} & $\begin{array}{c}\text { Homogenous } \\
\text { incorporate different } \\
\text { functional groups } \\
\end{array}$ & Cellulose acetoacetates & $\begin{array}{l}\text { diversely functionalized } \\
\text { cellulose derivatives }\end{array}$ & 46 \\
\hline Cellulose & {$\left[\mathrm{C}_{4} \mathrm{mim}\right] \mathrm{Cl}$} & $\begin{array}{l}\text { Homogeneous ring- } \\
\text { opening } \\
\text { polymerization } \\
\end{array}$ & $\begin{array}{l}\text { Cellulose-graft-poly }(\varepsilon- \\
\text { caprolactone })\end{array}$ & $\begin{array}{l}\text { Biomedicine and } \\
\text { nanotechnology }\end{array}$ & 47 \\
\hline Cellulose & {$\left[\mathrm{C}_{4} \mathrm{mim}\right] \mathrm{Cl}$} & $\begin{array}{l}\text { Homogeneous } \\
\text { polymerization - } \\
\text { Electrospraying }\end{array}$ & $\begin{array}{c}\text { Round-like nanoscaled } \\
\text { particles from cellulose-graft- } \\
\text { poly( } \varepsilon \text {-caprolactone) }\end{array}$ & $\begin{array}{l}\text { Controlled delivery of } \\
\text { hydrophilic drugs }\end{array}$ & 48 \\
\hline Cellulose & {$\left[\mathrm{C}_{4} \mathrm{mim}\right] \mathrm{Cl}$} & $\begin{array}{l}\text { Homogeneous } \\
\text { polymerization }\end{array}$ & $\begin{array}{c}\text { cellulose-graft- poly(lactide) } \\
\text { nanomicelles }\end{array}$ & Antitumor drug carriers & 49 \\
\hline Cotton pulp & {$[\mathrm{Amim}][\mathrm{Cl}]$} & $\begin{array}{l}\text { dissolution-regenerati } \\
\text { on-supercritical } \\
\text { drying route } \\
\end{array}$ & Cellulose aerogel membranes & $\begin{array}{l}\text { Gel polymer electrolyte to } \\
\text { the fabrication of lithium- } \\
\text { ion batteries }\end{array}$ & 55 \\
\hline Methyl cellulose & {$[\mathrm{G} 4 \mathrm{Li}]^{+}[\mathrm{TFSI}]$} & Casting & Solid iongel electrolytes & $\begin{array}{l}\text { Suitable for lithium metal } \\
\text { battery }\end{array}$ & 56 \\
\hline $\begin{array}{l}\text { Hydroxypropyl } \\
\text { cellulose }\end{array}$ & $\begin{array}{l}\text { 1-methyl- 3- } \\
\text { propylimidazolium } \\
\text { iodide }\end{array}$ & & Gel polymer electrolytes & $\begin{array}{l}\text { Dye-sensitized solar cell } \\
\text { applications }\end{array}$ & 57 \\
\hline $\begin{array}{l}\text { Microcrystalline } \\
\text { cellulose and } \\
\text { chitin }\end{array}$ & {$[$ Emim]OAc } & $\begin{array}{l}\text { Molding/gelation (“3D } \\
\text { gels”) or casting } \\
\text { (membranes) }\end{array}$ & $\begin{array}{l}\text { Composite 3D hydrogels and } \\
\text { membranes }\end{array}$ & $\begin{array}{c}\text { low density - high porosity } \\
\text { - high tensile strength } \\
\text { membranes }\end{array}$ & 64 \\
\hline $\begin{array}{l}\text { Cellulose acetate } \\
\text { and natural wool }\end{array}$ & {$\left[\mathrm{C}_{4} \mathrm{mim}\right][\mathrm{Cl}]$} & Blending & Wool/cellulose acetate blends & $\begin{array}{c}\text { Novel natural wool } \\
\text { blended materials }\end{array}$ & 70 \\
\hline $\begin{array}{l}\text { Microcrystalline } \\
\text { cellulose and } \\
\text { keratin from three } \\
\text { sources }\end{array}$ & {$\left[\mathrm{C}_{4} \operatorname{mim}\right][\mathrm{Cl}]$} & Casting - washing & composites & $\begin{array}{l}\text { drug delivery and wound } \\
\text { dressing }\end{array}$ & 71 \\
\hline $\begin{array}{l}\text { Microcrystalline } \\
\text { cellulose and silk }\end{array}$ & {$[\mathrm{Amim}][\mathrm{Cl}]$} & Regeneration in water. & Cellulose/silk composite & & 72 \\
\hline Cellulose & {$[\mathrm{Emim}] \mathrm{OAc}$} & Blending & cellulose/silk membranes & implantable device & 73 \\
\hline $\begin{array}{l}\text { Microcrystalline } \\
\text { cellulose }\end{array}$ & {$\left[\mathrm{C}_{4} \mathrm{mim}\right] \mathrm{Cl}$} & casting method & $\begin{array}{c}\text { Regenerated } \\
\text { cellulose/montmorillonite } \\
\text { nanocomposite }\end{array}$ & $\begin{array}{l}\text { Nanocomposite with } \\
\text { advanced properties }\end{array}$ & 76 \\
\hline $\begin{array}{l}\text { Microcrystalline } \\
\text { cellulose }\end{array}$ & {$\left[\mathrm{C}_{4} \mathrm{mim}\right] \mathrm{Cl}$} & $\begin{array}{l}\text { In presence of acid or } \\
\text { base }\end{array}$ & $\begin{array}{c}\text { Cellulose/monetite or } \\
\text { cellulose/chlorapatite } \\
\text { nanocoposites }\end{array}$ & $\begin{array}{l}\text { Scaffolds for bone tissue } \\
\text { engineering }\end{array}$ & 87 \\
\hline $\begin{array}{c}\text { Alkali extraction } \\
\text { cellulose }\end{array}$ & {$\left[\mathrm{C}_{4} \mathrm{mim}\right][\mathrm{Cl}]$} & $\begin{array}{c}\text { Cellulose } / \mathrm{CaCO}_{3} \\
\text { nanocomposites }\end{array}$ & $\begin{array}{c}\text { Microwave-assisted ionic } \\
\text { liquid method }\end{array}$ & Biomedical applications & 88 \\
\hline $\begin{array}{l}\text { Microcrystalline } \\
\text { cellulose and wool }\end{array}$ & {$\left[\mathrm{C}_{4} \operatorname{mim}\right][\mathrm{Cl}]$} & Re-precipitation & Blends & $\begin{array}{c}\text { Bioactive blend for } \\
\text { calcium phosphate } \\
\text { mineralization }\end{array}$ & 89 \\
\hline Cotton pulp & {$\left[\mathrm{C}_{2} \mathrm{mim}\right][\mathrm{DEP}]$} & wet-spinning method & $\begin{array}{c}\text { conductive multiwalled } \\
\text { carbon nanotubes -graphene } \\
\text { sheets - cellulose fiber }\end{array}$ & $\begin{array}{l}\text { high electrical conductivity } \\
\text { of } 1195 \mathrm{~S} / \mathrm{m}\end{array}$ & 90 \\
\hline Cellulose & {$\left[\mathrm{C}_{4} \operatorname{mim}\right][\mathrm{Cl}]$} & $\begin{array}{l}\text { sol-gel transition } \\
\text { method }\end{array}$ & $\begin{array}{c}\text { Novel magnetic cellulose- } \\
\text { chitosan composite } \\
\text { microspheres }\end{array}$ & $\begin{array}{c}\text { the activity recovery of } \\
\text { immobilized laccase } \\
\text { reached } 80.6 \%\end{array}$ & 91 \\
\hline Cellulose & {$\left[\mathrm{C}_{4} \operatorname{mim}\right][\mathrm{Cl}]$} & $\begin{array}{l}\text { sol-gel transition } \\
\text { method }\end{array}$ & $\begin{array}{c}\text { Novel magnetic cellulose- } \\
\text { chitosan composite } \\
\text { microspheres }\end{array}$ & $\begin{array}{l}\text { Adsorption capacity for } \\
\mathrm{Cu}(\mathrm{II}) \text { reached } 65.8 \mathrm{mg} / \mathrm{g}\end{array}$ & 92 \\
\hline Cellulose & {$[$ Emim]OAc } & $\begin{array}{l}\text { Forced-flow } \\
\text { impregnation }\end{array}$ & $\begin{array}{l}\text { Cellulose/silica composite } \\
\text { aerogels }\end{array}$ & $\begin{array}{l}\text { Aerogel with low thermal } \\
\text { conductivity }\end{array}$ & 96 \\
\hline Cotton pulp & {$[\mathrm{Amim}] \mathrm{Cl}$} & $\begin{array}{l}\text { Two-step sol-gel } \\
\text { technique }\end{array}$ & $\begin{array}{c}\text { Cellulose/silica composite } \\
\text { aerogels }\end{array}$ & $\begin{array}{l}\text { Good transparency with } \\
\text { light flame retardant - } \\
\text { enhanced mechanical } \\
\text { performance }\end{array}$ & 97 \\
\hline Wood chips & {$\left[\mathrm{C}_{4} \mathrm{mim}\right][\mathrm{Cl}]$} & $\begin{array}{c}\text { Dissolving and } \\
\text { separation }\end{array}$ & $\begin{array}{c}\text { Cellulose with high } \\
\text { molecular weight }\end{array}$ & & 100 \\
\hline $\begin{array}{c}\text { Pine, poplar, } \\
\text { Chinese parasol, } \\
\text { and catalpa wood } \\
\text { chips }\end{array}$ & {$[\mathrm{Amim}][\mathrm{Cl}]$} & $\begin{array}{l}\text { Dissolution - } \\
\text { precipitation }\end{array}$ & $\begin{array}{l}\text { Cellulose content is as high } \\
\text { as } 85 \%\end{array}$ & $\begin{array}{c}\text { Cellulose with a } \\
\text { homogeneous and dense } \\
\text { structure }\end{array}$ & 101 \\
\hline Cellulose & $\begin{array}{l}\text { (trioctylpentyl- } \\
\text { phosphonium }\end{array}$ & Hydrolysis & Glucose extraction & Cellulose hydrolysis & 104 \\
\hline
\end{tabular}




\begin{tabular}{|c|c|c|c|c|c|}
\hline & $\begin{array}{l}\text { hydrogen sulfate; } \\
{[\mathrm{P} 8,8,8,5][\mathrm{HSO} 4]}\end{array}$ & & & & \\
\hline $\begin{array}{l}\text { Microcrystalline } \\
\text { cellulose }\end{array}$ & $\begin{array}{c}\text { Four different ILs } \\
\text { systems }\end{array}$ & $\begin{array}{l}\text { Hydrolysis and } \\
\text { subsequent } \\
\text { degradation }\end{array}$ & 5-hydroxymethylfurfural & $\begin{array}{l}\text { One-pot synthesis of 5- } \\
\text { hydroxymethylfurfural } \\
\text { starting from cellulose }\end{array}$ & 109 \\
\hline
\end{tabular}

Cellulose extraction with ILs can produce high molecular weight cellulose with high purity and unique properties that is suitable for preparing new forms of blends and composites. Moreover, cellulose can be reconstituted and re-dissolved in ILs solutions for preparing strong fiber through electrospinning. Several novel high value cellulose materials can be obtained using ionic liquids. Carbon fibers with defined morphologies can be obtained from spun cellulose via carbonization reactions. Ionic liquids allow biopolymer extraction from raw biomass without significant polymer degradation. Regenerated biopolymers produced from IL solutions followed by coagulation exhibited promising properties compared to neat fibers. All these examples show the high polyvalence of IL processing of cellulose. However, further work is required to improve the energy balance of IL recycling, which is currently carried out by energy intensive evaporation procedures. 


\section{Acknowledgements}

A.S. thanks the National research Center, Cairo, Egypt for financial support (Project number 12020101).

\section{Author Contributions}

Ahmed Salama and Peter Hesemann contributed equally in the writing and publishing the current manuscript.

\section{Biographies}

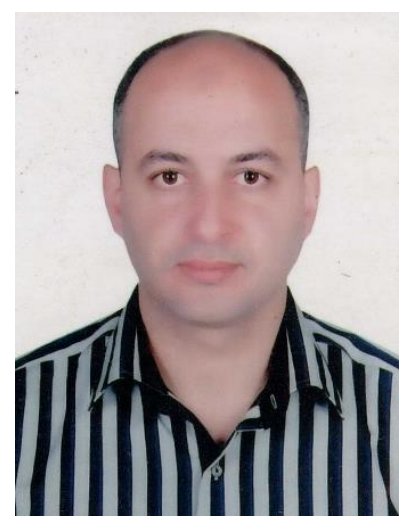

Ahmed SALAMA holds a PhD degree in chemistry from the University of Mansoura, Egypt (2013). During his PhD study, he joined Potsdam University in Germany for two years with Prof. Andreas Taubert where he was working on polysaccharides as bioactive materials for calcium phosphate mineralization. In 2015, he was a postdoc with Dr. Peter Hesemann at Montpellier University in France where he gained experience in developing new polysaccharides derivatives for water purification. In 2019, he became a group leader and Assistant Professor at the National Research Center in Cairo. His research interests are cellulose chemistry, ionic liquids and hybrid materials. He is particularly interested in potential industrial uses of cellulose and its application in preparation of high value materials for biomedical and environmental applications. 


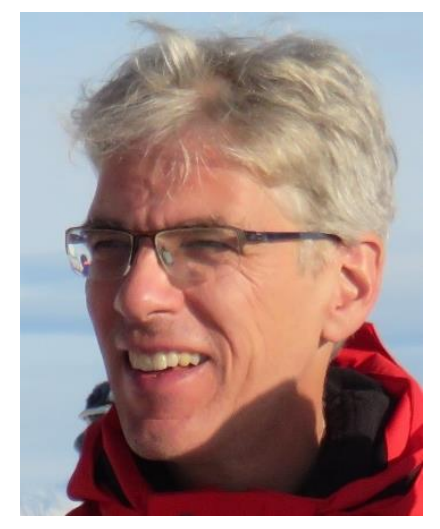

Dr. Peter HESEMANN graduated in 1991 and obtained his PhD in 1994 at the PhilippsUniversität Marburg/Germany. After a post-doctoral fellowship with R.J.P Corriu at the Université Montpellier/France in 1995-96, he joined CNRS as research scientist in 1997, and became CNRS senior scientist in 2011. Since 2018, he is the head of the CMOS (Chimie Moléculaire et Organisation du Solide) team of the Institut Charles Gerhardt in Montpellier. His research interests concern various aspects in molecular and materials chemistry, especially in the elaboration of functional ionic liquids, hybrid silicas and renewable materials for applications in adsorption, catalysis and the biomedical field. 


\section{References}

(1) Xia, Z.; Li, J.; Zhang, J.; Zhang, X.; Zheng, X.; Zhang, J. Processing and Valorization of Cellulose, Lignin and Lignocellulose Using Ionic Liquids. $J$. Bioresour. Bioprod. 2020, 5 (2), 79-95.

(2) Salama, A.; Shoueir, K. R.; Aljohani, H. A. Preparation of sustainable nanocomposite as new adsorbent for dyes removal. Fibers Polym. 2017, 18 (9).

(3) Abouzeid, R. E.; Khiari, R.; Salama, A.; Diab, M.; Beneventi, D.; Dufresne, A. In situ mineralization of nano-hydroxyapatite on bifunctional cellulose nano fi ber / polyvinyl alcohol / sodium alginate hydrogel using 3D printing. Int. J. Biol. Macromol. 2020, 160, 538-547.

(4) Abou-Zeid, R. E.; Awwad, N. S.; Nabil, S.; Salama, A.; Youssef, M. A. Oxidized alginate/gelatin decorated silver nanoparticles as new nanocomposite for dye adsorption. Int. J. Biol. Macromol. 2019, 141, 1280-1286.

(5) Shamshina, J. L.; Berton, P.; Rogers, R. D. Advances in Functional Chitin Materials: A Review. ACS Sustain. Chem. Eng. 2019, 7 (7), 6444-6457.

(6) Yang, J.; Lu, X.; Yao, X.; Li, Y.; Yang, Y.; Zhou, Q.; Zhang, S. Inhibiting degradation of cellulose dissolved in ionic liquids via amino acids. Green Chem. 2019, 2777-2787.

(7) Salama, A.; Shukry, N.; El-Sakhawy, M. Carboxymethyl cellulose-g-poly(2(dimethylamino) ethyl methacrylate) hydrogel as adsorbent for dye removal. Int. J. Biol. Macromol. 2015, 73, 72-75.

(8) Salama, A.; Etri, S.; Mohamed, S. A. A.; El-Sakhawy, M. Carboxymethyl cellulose prepared from mesquite tree: New source for promising nanocomposite materials. Carbohydr. Polym. 2018, 189, 138-144.

(9) Salama, A.; Shukry, N.; El-gendy, A.; El-sakhawy, M. Bioactive cellulose grafted soy protein isolate towards biomimetic calcium phosphate mineralization. Ind. Crop. Prod. 2017, 95, 170-174.

(10) Swatloski, R. P.; Spear, S. K.; Holbrey, J. D.; Rogers, R. D. Dissolution of cellose with Ionic Liquids. J. Am. Chem. Soc. 2002, 124 (18), 4974-4975.

(11) Idris, A.; Vijayaraghavan, R.; Rana, U. A.; Patti, A. F.; Macfarlane, D. R. Dissolution and regeneration of wool keratine in ionic liquids. Green Chem. 2014, 16, 2857-2864.

(12) Shamshina, J. L. Chitin in ionic liquids: Historical insights into the polymer's dissolution and isolation. A review. Green Chem. 2019, 21 (15), 3974-3993.

(13) Pereira, R. F. P.; Zehbe, K.; Günter, C.; Dos Santos, T.; Nunes, S. C.; Paz, F. A. A.; Silva, M. M.; Granja, P. L.; Taubert, A.; De Zea Bermudez, V. Ionic Liquid-Assisted Synthesis of Mesoporous Silk Fibroin/Silica Hybrids for Biomedical Applications. ACS Omega 2018, 3 (9), 10811-10822.

(14) Onwukamike, K. N.; Grelier, S.; Grau, E.; Cramail, H.; Meier, M. A. R. Critical Review on Sustainable Homogeneous Cellulose Modification: Why Renewability Is Not Enough. ACS Sustain. Chem. Eng. 2019, 7 (2), 18261840. 
(15) Salama, A. New sustainable hybrid material as adsorbent for dye removal from aqueous solutions. J. Colloid Interface Sci. 2017, 487, 348-353.

(16) Salama, A.; Abou-Zeid, R. E.; Cruz-Maya, I.; Guarino, V. Soy protein hydrolysate grafted cellulose nanofibrils with bioactive signals for bone repair and regeneration. Carbohydr. Polym. 2020, 229 (August 2019), 115472.

(17) Salama, A. Cellulose/calcium phosphate hybrids: New materials for biomedical and environmental applications. Int. J. Biol. Macromol. 2019, 127, 606-617.

(18) Elschner, T.; Kötteritzsch, M.; Heinze, T. Synthesis of cellulose tricarbonates in 1-butyl-3-methylimidazolium chloride/pyridine. Macromol. Biosci. 2014, 14 (2), 161-165.

(19) Nishiyama, Y.; Langan, P.; Chanzy, H. Crystal Structure and HydrogenBonding System in Cellulose I $\beta$ from Synchrotron X-ray and Neutron Fiber Diffraction. J. Am. Chem. Soc. 2002, 124 (31), 9074-9082.

(20) Plechkova, N. V.; Seddon, K. R. Applications of ionic liquids in the chemical industry. Chem. Soc. Rev. 2008, 37 (1), 123-150.

(21) Dupont, J. On the solid, liquid and solution structural organization of imidazolium ionic liquids. J. Braz. Chem. Soc. 2004, 15 (3), 341-350.

(22) Liu, Y.-R.; Thomsen, K.; Nie, Y.; Zhang, S.-J.; Meyer, A. S. Predictive screening of ionic liquids for dissolving cellulose and experimental verification. Green Chem. 2016, 18 (23), 6246-6254.

(23) Andanson, J.-M.; Bordes, E.; Devémy, J.; Leroux, F.; Pádua, A. A. H.; Gomes, M. F. C. Understanding the role of co-solvents in the dissolution of cellulose in ionic liquids. Green Chem. 2014, 16 (5), 2528-2538.

(24) Samikannu, R.; Shukla, S. K.; Samikannu, A.; Mikkola, J. P. Lutidinium-based ionic liquids for efficient dissolution of cellulose. New J. Chem. 2019, 43 (5), 2299-2306.

(25) Verma, C.; Mishra, A.; Chauhan, S.; Verma, P.; Srivastava, V.; Quraishi, M. A.; Ebenso, E. E. Dissolution of cellulose in ionic liquids and their mixed cosolvents: A review. Sustain. Chem. Pharm. 2019, 13, 100162.

(26) Luo, N.; Lv, Y.; Wang, D.; Zhang, J.; Wu, J.; He, J.; Zhang, J. Direct visualization of solution morphology of cellulose in ionic liquids by conventional TEM at room temperature. Chem. Commun. 2012, 48 (50), 6283.

(27) Li, Y.; Wang, J.; Liu, X.; Zhang, S. Towards a molecular understanding of cellulose dissolution in ionic liquids: Anion/cation effect, synergistic mechanism and physicochemical aspects. Chem. Sci. 2018, 9 (17), 4027-4043.

(28) Wang, H.; Gurau, G.; Rogers, R. D. Ionic liquid processing of cellulose. Chem. Soc. Rev. 2012, 41 (4), 1519-1537.

(29) Hermanutz, F.; Vocht, M. P.; Panzier, N.; Buchmeiser, M. R. Processing of Cellulose Using Ionic Liquids. Macromol. Mater. Eng. 2019, 304 (2), 1-8.

(30) Spörl, J. M.; Batti, F.; Vocht, M.-P.; Raab, R.; Müller, A.; Hermanutz, F.; Buchmeiser, M. R. Ionic Liquid Approach Toward Manufacture and Full 
Recycling of All-Cellulose Composites. Macromol. Mater. Eng. 2018, 303 (1), 1700335 .

(31) Davé, V.; Glasser, W. G. Cellulose-based fibres from liquid crystalline solutions: 5. Processing and morphology of $\mathrm{CAB}$ blends with lignin. Polymer (Guildf). 1997, 38 (9), 2121-2126.

(32) Postema, A. R.; Liou, K.; Wudl, F.; Smith, P. Highly oriented low-modulus materials from liquid-crystalline polymers: the ultimate penalty for solubilizing alkyl side chains. Macromolecules 1990, 23 (6), 1842-1845.

(33) Zhu, C.; Richardson, R. M.; Potter, K. D.; Koutsomitopoulou, A. F.; Van Duijneveldt, J. S.; Vincent, S. R.; Wanasekara, N. D.; Eichhorn, S. J.; Rahatekar, S. S. High modulus regenerated cellulose fibers spun from a low molecular weight microcrystalline cellulose solution. ACS Sustain. Chem. Eng. 2016, 4 (9), 4545-4553.

(34) Koga, H.; Nogi, M.; Isogai, A. Ionic Liquid Mediated Dispersion and Support of Functional Molecules on Cellulose Fibers for Stimuli-Responsive Chromic Paper Devices. ACS Appl. Mater. Interfaces 2017, 9 (46), 40914-40920.

(35) Quan, S.-L.; Kang, S.-G.; Chin, I.-J. Characterization of cellulose fibers electrospun using ionic liquid. Cellulose 2010, 17 (2), 223-230.

(36) Meli, L.; Miao, J.; Dordick, J. S.; Linhardt, R. J. Electrospinning from room temperature ionic liquids for biopolymer fiber formation. Green Chem. 2010, 12 (11), 1883-1892.

(37) Kim, C.-W.; Kim, D.-S.; Kang, S.-Y.; Marquez, M.; Joo, Y. L. Structural studies of electrospun cellulose nanofibers. Polymer (Guildf). 2006, 47 (14), 5097-5107.

(38) Spörl, J. M.; Ota, A.; Son, S.; Massonne, K.; Hermanutz, F.; Buchmeiser, M. R. Carbon fibers prepared from ionic liquid-derived cellulose precursors. Mater. Today Commun. 2016, 7, 1-10.

(39) Byrne, N.; Leblais, A.; Fox, B. Preparation of polyacrylonitrile-natural polymer composite precursors for carbon fiber using ionic liquid co solvent solutions. J. Mater. Chem. A 2014, 2 (10), 3424-3429.

(40) Salama, A.; Hasanin, M.; Hesemann, P. Synthesis and antimicrobial properties of new chitosan derivatives containing guanidinium groups. Carbohydr. Polym. 2020, 116363.

(41) Schmidt, S.; Liebert, T.; Heinze, T. Synthesis of soluble cellulose tosylates in an eco-friendly medium. Green Chem. 2014, 16 (4), 1941-1946.

(42) Gericke, M.; Schaller, J.; Liebert, T.; Fardim, P.; Meister, F.; Heinze, T. Studies on the tosylation of cellulose in mixtures of ionic liquids and a cosolvent. Carbohydr. Polym. 2012, 89 (2), 526-536.

(43) Pfeifer, A.; Gericke, M.; Heinze, T. Advanced Industrial and Engineering Polymer Research Synthesis and characterization of novel water-soluble 6deoxy-6- ( 2- amino-2- ( hydroxymethyl ) propane-1 , 3-diol ) cellulose derivatives. Adv. Ind. Eng. Polym. Res. 2020, 3 (2), 77-82. 
(44) Elschner, T.; Ganske, K.; Heinze, T. Synthesis and aminolysis of polysaccharide carbonates. Cellulose 2013, 20 (1), 339-353.

(45) Labafzadeh, S. R.; Helminen, K. J.; Kilpeläinen, I.; King, A. W. T. Synthesis of cellulose methylcarbonate in ionic liquids using dimethylcarbonate. ChemSusChem 2015, 8 (1), 77-81.

(46) Liu, H.; Rong, L.; Wang, B.; Mao, Z.; Xie, R.; Xu, H.; Zhang, L.; Zhong, Y.; Sui, X. Facile synthesis of cellulose derivatives based on cellulose acetoacetate. Carbohydr. Polym. 2017, 170, 117-123.

(47) Guo, Y.; Wang, X.; Shen, Z.; Shu, X.; Sun, R. Preparation of cellulose- graft poly ( $\varepsilon$-caprolactone ) nanomicelles by homogeneous ROP in ionic liquid. Carbohydr. Polym. 2013, 92 (1), 77-83.

(48) Zuppolini, S.; Maya, I. C.; Diodato, L.; Guarino, V.; Borriello, A.; Ambrosio, L. Materials Science \& Engineering C Self-associating cellulose-graft-poly ( $\varepsilon-$ caprolactone ) to design nanoparticles for drug release. Mater. Sci. Eng. C 2020, 108 (July 2019), 110385.

(49) Guo, Y.; Wang, X.; Shu, X.; Shen, Z.; Sun, R. Self-Assembly and Paclitaxel Loading Capacity of Cellulose- graft - poly(lactide) Nanomicelles. J. Agric. Food Chem. 2012, 60, 3900-3908.

(50) Chen, W.; Yu, H.; Lee, S.-Y.; Wei, T.; Li, J.; Fan, Z. Nanocellulose: a promising nanomaterial for advanced electrochemical energy storage. Chem. Soc. Rev. 2018, 47 (8), 2837-2872.

(51) Gebresilassie Eshetu, G.; Armand, M.; Scrosati, B.; Passerini, S. Energy Storage Materials Synthesized from Ionic Liquids. Angew. Chemie Int. Ed. 2014, 53 (49), 13342-13359.

(52) Croce, F.; Focarete, M. L.; Hassoun, J.; Meschini, I.; Scrosati, B. A safe, highrate and high-energy polymer lithium-ion battery based on gelled membranes prepared by electrospinning. Energy Environ. Sci. 2011, 4 (3), 921.

(53) Xu, Q.; Kong, Q.; Liu, Z.; Wang, X.; Liu, R.; Zhang, J.; Yue, L.; Duan, Y.; Cui, G. Cellulose/Polysulfonamide Composite Membrane as a High Performance Lithium-Ion Battery Separator. ACS Sustain. Chem. Eng. 2014, 2 (2), 194-199.

(54) Cheng, X.; Pan, J.; Zhao, Y.; Liao, M.; Peng, H. Gel Polymer Electrolytes for Electrochemical Energy Storage. Adv. Energy Mater. 2018, 8 (7), 1702184.

(55) Wan, J.; Zhang, J.; Yu, J.; Zhang, J. Cellulose Aerogel Membranes with a Tunable Nanoporous Network as a Matrix of Gel Polymer Electrolytes for Safer Lithium-Ion Batteries. ACS Appl. Mater. Interfaces 2017, 9 (29), 2459124599.

(56) Chereddy, S.; Aguirre, J.; Dikin, D.; Wunder, S. L.; Chinnam, P. R. Gel Electrolyte Comprising Solvate Ionic Liquid and Methyl Cellulose. ACS Appl. Energy Mater. 2020, 3 (1), 279-289.

(57) Khanmirzaei, M. H.; Ramesh, S.; Ramesh, K. Hydroxypropyl Cellulose Based Non-Volatile Gel Polymer Electrolytes for Dye-Sensitized Solar Cell Applications using 1-methyl-3-propylimidazolium iodide ionic liquid. Sci. Rep. 
2015, 5 (May), 1-7.

(58) Satani, H.; Kuwata, M.; Shimizu, A. Simple and environmentally friendly preparation of cellulose hydrogels using an ionic liquid. Carbohydr. Res. 2020, 494 (February), 108054.

(59) Liang, X.; Qu, B.; Li, J.; Xiao, H.; He, B.; Qian, L. Preparation of cellulosebased conductive hydrogels with ionic liquid. React. Funct. Polym. 2015, 86, $1-6$.

(60) Salama, A.; Hesemann, P. New N-guanidinium chitosan/silica ionic microhybrids as efficient adsorbent for dye removal from waste water. Int. J. Biol. Macromol. 2018, 111, 762-768.

(61) Salama, A.; Hesemann, P. Synthesis of N-Guanidinium-chitosan/silica hybrid composites: Efficient adsorbents for anionic pollutants. J. Polym. Environ. 2018, 26 (5), 1986-1997.

(62) Irie, M.; Fukaminato, T.; Matsuda, K.; Kobatake, S. Photochromism of Diarylethene Molecules and Crystals: Memories, Switches, and Actuators. Chem. Rev. 2014, 114 (24), 12174-12277.

(63) Hao, Y.; Cui, Y.; Peng, J.; Zhao, N.; Li, S.; Zhai, M. Preparation of graphene oxide/cellulose composites in ionic liquid for Ce (III) removal. Carbohydr. Polym. 2019, 208 (June 2018), 269-275.

(64) Berton, P.; Shen, X.; Rogers, R. D.; Shamshina, J. L. 110th Anniversary: HighMolecular-Weight Chitin and Cellulose Hydrogels from Biomass in Ionic Liquids without Chemical Crosslinking. Ind. Eng. Chem. Res. 2019, 58 (43), 19862-19876.

(65) Van Vlierberghe, S.; Dubruel, P.; Schacht, E. Biopolymer-Based Hydrogels As Scaffolds for Tissue Engineering Applications: A Review. Biomacromolecules 2011, 12 (5), 1387-1408.

(66) Shu, X. ; Zhu, K. . Controlled drug release properties of ionically cross-linked chitosan beads: the influence of anion structure. Int. J. Pharm. 2002, 233 (1-2), 217-225.

(67) Salama, A. Chitosan based hydrogel assisted spongelike calcium phosphate mineralization for in-vitro BSA release. Int. J. Biol. Macromol. 2018, 108, 471-476.

(68) Salama, A.; El-Sakhawy, M. Preparation of polyelectrolyte/calcium phosphate hybrids for drug delivery application. Carbohydr. Polym. 2014, 113, 500-506.

(69) Mundsinger, K.; Müller, A.; Beyer, R.; Hermanutz, F.; Buchmeiser, M. R. Multifilament cellulose/chitin blend yarn spun from ionic liquids. Carbohydr. Polym. 2015, 131, 34-40.

(70) Hameed, N.; Guo, Q. Natural wool / cellulose acetate blends regenerated from the ionic liquid 1-butyl-3-methylimidazolium chloride. Carbohydr. Polym. 2009, 78 (4), 999-1004.

(71) Tran, C. D.; Prosencyes, F.; Franko, M.; Benzi, G. Synthesis, structure and antimicrobial property of green composites from cellulose, wool, hair and 
chicken feather. Carbohydr. Polym. 2016, 151, 1269-1276.

(72) Hadadi, A.; Whittaker, J. W.; Verrill, D. E.; Hu, X.; Larini, L.; Salas-De La Cruz, D. A Hierarchical Model to Understand the Processing of Polysaccharides/Protein-Based Films in Ionic Liquids. Biomacromolecules 2018, 19 (10), 3970-3982.

(73) Singh, N.; Rahatekar, S. S.; Koziol, K. K. K.; Ng, T. S.; Patil, A. J.; Mann, S.; Hollander, A. P.; Kafienah, W. Directing chondrogenesis of stem cells with specific blends of cellulose and silk. Biomacromolecules 2013, 14 (5), 12871298.

(74) Blessing, B.; Trout, C.; Morales, A.; Rybacki, K.; Love, S. A.; Lamoureux, G.; O’Malley, S. M.; Hu, X.; Salas-de la Cruz, D. The Impact of Composition and Morphology on Ionic Conductivity of Silk/Cellulose Bio-Composites Fabricated from Ionic Liquid and Varying Percentages of Coagulation Agents. Int. J. Mol. Sci. 2020, 21 (13), 4695-4715.

(75) Salama, A. Functionalized hybrid materials assisted organic dyes removal from aqueous solutions. Environ. Nanotechnology, Monit. Manag. 2016, 6, 159-163.

(76) Mahmoudian, S.; Wahit, M. U.; Ismail, A. F.; Yussuf, A. A. Preparation of regenerated cellulose/montmorillonite nanocomposite films via ionic liquids. Carbohydr. Polym. 2012, 88 (4), 1251-1257.

(77) Salama, A. Dicarboxylic cellulose decorated with silver nanoparticles as sustainable antibacterial nanocomposite material. Environ. Nanotechnology, Monit. Manag. 2017, 8, 228-232.

(78) Kumar, A. S. K.; Kalidhasan, S.; Rajesh, V.; Rajesh, N. Application of cellulose-clay composite biosorbent toward the effective adsorption and removal of chromium from industrial wastewater. Ind. Eng. Chem. Res. 2012, $51(1), 58-69$.

(79) Zhang, H.; Wang, Z. G.; Zhang, Z. N.; Wu, J.; Zhang, J.; He, J. S. Regenerated-Cellulose/Multiwalled-Carbon-Nanotube Composite Fibers with Enhanced Mechanical Properties Prepared with the Ionic Liquid 1-Allyl-3methylimidazolium Chloride. Adv. Mater. 2007, 19 (5), 698-704.

(80) Salama, A.; Hesemann, P. Synthesis and characterization of N -guanidinium chitosan / silica ionic hybrids as templates for calcium phosphate mineralization. Int. J. Biol. Macromol. 2020, 147, 276-283.

(81) Hassan, H.; Salama, A.; El-ziaty, A. K.; El-sakhawy, M. International Journal of Biological Macromolecules New chitosan / silica / zinc oxide nanocomposite as adsorbent for dye removal. Int. J. Biol. Macromol. 2019, $131,520-526$.

(82) Zhou, Y.; Schattka, J. Room-temperature ionic liquids as template to monolithic mesoporous silica with wormlike pores via a sol-gel nanocasting technique. Nano Lett. 2004, 4 (3), 477-481.

(83) Kaper, H.; Endres, F.; Djerdj, I.; Antonietti, M.; Smarsly, B. M.; Maier, J.; Hu, Y.-S. Direct low-temperature synthesis of rutile nanostructures in ionic liquids. Small 2007, 3 (10), 1753-1763. 
(84) Taubert, A. CuCl Nanoplatelets from an Ionic Liquid-Crystal Precursor. Angew. Chemie 2004, 116 (40), 5494-5496.

(85) Parnham, E. R.; Morris, R. E. Ionothermal synthesis of zeolites, metal-organic frameworks, and inorganic-organic hybrids. Acc. Chem. Res. 2007, 40 (10), 1005-1013.

(86) Taubert, A.; Li, Z. Inorganic materials from ionic liquids. Dalton Trans. 2007, No. 7, 723-727.

(87) Salama, A.; Neumann, M.; Günter, C.; Taubert, A. Ionic liquid-assisted formation of cellulose/calcium phosphate hybrid materials. Beilstein J. Nanotechnol. 2014, 5, 1553-1568.

(88) Ma, M. G.; Dong, Y. Y.; Fu, L. H.; Li, S. M.; Sun, R. C. Cellulose/CaCO3 nanocomposites: Microwave ionic liquid synthesis, characterization, and biological activity. Carbohydr. Polym. 2013, 92 (2), 1669-1676.

(89) Salama, A.; El-Sakhawy, M. Regenerated cellulose/wool blend enhanced biomimetic hydroxyapatite mineralization. Int. J. Biol. Macromol. 2016, 92 , 920-925.

(90) Liu, Y.; Wang, Y.; Nie, Y.; Wang, C.; Ji, X.; Zhou, L.; Pan, F.; Zhang, S. Preparation of MWCNTs-Graphene-Cellulose Fiber with Ionic Liquids. ACS Sustain. Chem. Eng. 2019, 7 (24), 20013-20021.

(91) Peng, S.; Meng, H.-C.; Zhou, L.; Chang, J. Synthesis of Novel Magnetic Cellulose-Chitosan Composite Microspheres and Their Application in Laccase Immobilization. J. Nanosci. Nanotechnol. 2014, 14 (9), 7010-7014.

(92) Peng, S.; Meng, H.; Ouyang, Y.; Chang, J. Nanoporous magnetic cellulosechitosan composite microspheres: Preparation, characterization, and application for $\mathrm{Cu}(\mathrm{II})$ adsorption. Ind. Eng. Chem. Res. 2014, 53 (6), 2106-2113.

(93) Li, B.; Zhang, Q.; Pan, Y.; Li, Y.; Huang, Z.; Li, M.; Xiao, H. Functionalized porous magnetic cellulose/Fe3O4 beads prepared from ionic liquid for removal of dyes from aqueous solution. Int. J. Biol. Macromol. 2020, 163, 309-316.

(94) Zhou, J.; Hsieh, Y.-L. Nanocellulose aerogel-based porous coaxial fibers for thermal insulation. Nano Energy 2020, 68, 104305-104314.

(95) Niu, F.; Wu, N.; Yu, J.; Ma, X. Gelation, flame retardancy, and physical properties of phosphorylated microcrystalline cellulose aerogels. Carbohydr. Polym. 2020, 242, 116422.

(96) Demilecamps, A.; Beauger, C.; Hildenbrand, C.; Rigacci, A.; Budtova, T. Cellulose-silica aerogels. Carbohydr. Polym. 2015, 122, 293-300.

(97) Yuan, B.; Zhang, J.; Mi, Q.; Yu, J.; Song, R.; Zhang, J. Transparent CelluloseSilica Composite Aerogels with Excellent Flame Retardancy via an in Situ SolGel Process. ACS Sustain. Chem. Eng. 2017, 5 (11), 11117-11123.

(98) Rieland, J. M.; Love, B. J. Ionic liquids: A milestone on the pathway to greener recycling of cellulose from biomass. Resour. Conserv. Recycl. 2020, 155 (December 2019), 104678. 
(99) Younes, I.; Rinaudo, M. Chitin and Chitosan Preparation from Marine Sources. Structure, Properties and Applications. Mar. Drugs 2015, 13 (3), 1133-1174.

(100) Fort, D. a.; Remsing, R. C.; Swatloski, R. P.; Moyna, P.; Moyna, G.; Rogers, R. D. Can ionic liquids dissolve wood? Processing and analysis of lignocellulosic materials with 1-n-butyl-3-methylimidazolium chloride. Green Chem. 2007, 9 (1), 63-69.

(101) Wang, X.; Li, H.; Cao, Y.; Tang, Q. Cellulose extraction from wood chip in an ionic liquid 1-allyl-3-methylimidazolium chloride (AmimCl). Bioresour. Technol. 2011, 102 (17), 7959-7965.

(102) Fu, D.; Mazza, G.; Tamaki, Y. Lignin extraction from straw by ionic liquids and enzymatic hydrolysis of the cellulosic residues. J. Agric. Food Chem. 2010, 58 (5), 2915-2922.

(103) Amarasekara, A. S.; Wiredu, B. Degradation of Cellulose in Dilute Aqueous Solutions of Acidic Ionic Liquid 1-(1-Propylsulfonic)-3-methylimidazolium Chloride, and $\mathrm{p}$-Toluenesulfonic Acid at Moderate Temperatures and Pressures. Ind. Eng. Chem. Res. 2011, 50 (21), 12276-12280.

(104) Kuroda, K.; Miyamura, K.; Satria, H.; Takada, K.; Ninomiya, K.; Takahashi, K. Hydrolysis of Cellulose Using an Acidic and Hydrophobic Ionic Liquid and Subsequent Separation of Glucose Aqueous Solution from the Ionic Liquid and 5-(Hydroxymethyl)furfural. ACS Sustain. Chem. Eng. 2016, 4 (6), 3352-3356.

(105) Zhou, J.; Huang, T.; Zhao, Y.; Xia, Z.; Xu, Z.; Jia, S.; Wang, J.; Zhang, Z. C. Solvent Mediation for Enhanced Separation of 5-Hydroxymethylfurfural from 1-Butyl-3-Methylimidazolium Chloride. Ind. Eng. Chem. Res. 2015, 54 (32), 7977-7983.

(106) Aid, T.; Koel, M.; Lopp, M.; Vaher, M. Metal-Catalyzed Degradation of Cellulose in Ionic Liquid Media. Inorganics 2018, 6 (3), 78-89.

(107) Zhou, L.; He, Y.; Ma, Z.; Liang, R.; Wu, T.; Wu, Y. One-step degradation of cellulose to 5-hydroxymethylfurfural in ionic liquid under mild conditions. Carbohydr. Polym. 2015, 117, 694-700.

(108) Zhao, H.; Holladay, J. E.; Brown, H.; Zhang, Z. C. Metal Chlorides in Ionic Liquid Solvents Convert Sugars to 5-Hydroxymethylfurfural. Science (80-. ). 2007, 316 (5831), 1597-1600.

(109) Chiappe, C.; Rodriguez Douton, M. J.; Mezzetta, A.; Pomelli, C. S.; Assanelli, G.; De Angelis, A. R. Recycle and Extraction: Cornerstones for an Efficient Conversion of Cellulose into 5-Hydroxymethylfurfural in Ionic Liquids. ACS Sustain. Chem. Eng. 2017, 5 (6), 5529-5536. 